\title{
Bone morphogenetic proteins mediate crosstalk between cancer cells and the tumour microenvironment at primary tumours and metastases (Review)
}

\author{
ZHIWEI SUN ${ }^{1}$, SHUO CAI ${ }^{2}$, CATHERINE ZABKIEWICZ ${ }^{2}$, CHANG LIU $^{2}$ and LIN YE ${ }^{2}$ \\ ${ }^{1}$ VIP-II Division of Medical Department, Key Laboratory of Carcinogenesis and Translational Research \\ (Ministry of Education, Beijing), Peking University Cancer Hospital and Institute, Beijing 100142, P.R. China; \\ ${ }^{2}$ Cardiff China Medical Research Collaborative, Division of Cancer and Genetics, \\ Cardiff University School of Medicine, Cardiff CF14 4XN, United Kingdom
}

Received September 13, 2019; Accepted February 28, 2020

DOI: 10.3892/ijo.2020.5030

\begin{abstract}
Bone morphogenetic proteins (BMP) are pluripotent molecules, co-ordinating cellular functions from early embryonic and postnatal development to tissue repair, regeneration and homeostasis. They are also involved in tumourigenesis, disease progression and the metastasis of various solid tumours. Emerging evidence has indicated that BMPs are able to promote disease progression and metastasis by orchestrating communication between cancer cells and the surrounding microenvironment. The interactions occur between BMPs and epidermal growth factor receptor, hepatocyte growth factor, fibroblast growth factor, vascular endothelial growth factor and extracellular matrix components. Overall, these interactions co-ordinate the cellular functions of tumour cells and other types of cell in the tumour to promote the growth of the primary tumour, local invasion, angiogenesis and metastasis, and the establishment and survival of cancer cells in the metastatic niche. Therefore, the present study aimed to provide an informative summary of the involvement of BMPs in the tumour microenvironment.
\end{abstract}

\section{Contents}

1. Introduction

2. Signal transduction of BMP

3. Interaction between BMP and other signalling pathways

4. BMP and tumour-associated angiogenesis

Correspondence to: Dr Lin Ye, Cardiff China Medical Research Collaborative, Division of Cancer and Genetics, Cardiff University School of Medicine, Henry Wellcome Building, Academic Avenue, Cardiff CF14 4XN, United Kingdom

E-mail: YeL@Cardiff.ac.uk

Key words: bone morphogenetic protein, cancer, tumour microenvironment, angiogenesis and metastasis

\section{BMPs and EMT}

6. BMP-co-ordinated interaction between cancer cells and other cellular/non-cellular parts within the tumour

7. BMP-related activities in bone metastasis

8. Therapeutic potential and perspectives

\section{Introduction}

Bone morphogenetic proteins (BMPs) were originally termed by Urist (1) in 1965 as it induced bone formation ectopically. They are members of the transforming growth factor $\beta$ (TGF $\beta$ ) superfamily (2). In humans, there have been $>20$ BMPs identified. They are pluripotent molecules that co-ordinate cellular differentiation, proliferation and apoptosis in early embryonic and postnatal development $(3,4)$. They are essential in controlling tissue repair, regeneration and homeostasis (4-6).

BMPs serve important roles in tumourigenesis, disease progression and the metastasis of various solid tumours (7-10). BMP signalling has been found to be both oncogenic and tumour suppressing, depending on context. For example, studies have shown that BMPs are upregulated in certain tumours, particularly those originating from soft tissues such as osteosarcomas, chondrosarcoma, ameloblastoma and salivary tumours (11-14). They are actively involved in cancer development and metastasis (7-10). BMP-6 overexpression in prostate cancer is associated with osteoblastic bone metastasis (7). BMP-4 may promote the invasion and motility of breast cancer cells via upregulation of matrix metalloproteinase (MMP)1 and C-X-C chemokine receptor 4 (8). The above studies indicate an oncogenic effect of BMPs in certain solid tumours. In contrast, impairments in BMP signalling observed in colorectal cancers and polyposis syndromes suggest a tumour suppressor role in these situations (15). Our previous study reported that BMP-10 inhibits prostate cancer cell growth by promoting apoptosis via Smad-independent signalling, and that it can also reduce the invasiveness and motility of cancer cells (9). BMP-4 can also reduce the capacity of myeloid- derived suppressor cells to prevent metastasis of breast cancer cells (10). It appears that the same BMPs may have varied roles in different types of tumour, potentially due to the involvement of distinct downstream molecules. 
As pleiotropic growth factors, BMPs are actively involved in tumorigenesis, disease progression and metastasis, not only directly due to their own signalling pathway, but also via complex interactions with other growth factors and other signalling pathways (16-24). More importantly, BMP-mediated interactions between cancer cells and the local environment also occur during the development of both the primary tumour and metastasis, forming a large, intricate network that promotes the epithelial to mesenchymal transition (EMT) of tumours, remodelling of tumour-associated extracellular matrix (ECM), angiogenesis and bone metastasis.

\section{Signal transduction of BMP}

Both type I receptors [activin A receptor type I (ACVR)-like 1, ACVR1, BMP receptor (BMPR)1A, ACVR1B, TGF $\beta$ receptor (TGF $\beta R$ )1, BMPR1B and ACVR1C] and type II receptors (TGF $\beta$ R2, TGF $\beta$ R3, BMPR2, ACVR2A and ACVR2B) are indispensable for signal transduction of TGF $\beta$ (25). The type I receptors are also respectively known as activin receptor-like kinase (ALK)1-7. Certain type I receptors (ALK1, ALK3 and ALK6) exhibit a higher binding affinity to BMPs (25). Smad-dependent signalling will be induced by the preformed hetero-oligomeric complexes (PFC) upon binding with BMP ligands (26,27). Alternatively, upon binding between BMP ligands and type I receptors, type II receptors are then recruited, leading to the formation of BMP-induced signalling complexes, which activate the Smad-independent pathway $(26,27)$.

Smad-dependent pathway. As transcription factors, Smad proteins are vital for intracellular transduction of BMP signalling $(25,27,28)$. There are three subgroups of Smad proteins: Smad 1, 2, 3, 5 and 8 are pathway-restricted Smads (R-Smads); Smad 4 is known as a common mediator Smad; and Smad 6 and 7 are inhibitory Smads (I-Smads) $(27,28)$. After BMP homodimers or heterodimers bind to the PFC, the glycine-serine region of type I receptors is phosphorylated by the type II receptor, leading to the activation and translocation of R-Smads (Smad 1, 5 and 8) into the nucleus, and regulation of BMP-responsive genes such as Id1-3, Smad 6/7, type I collagen, JunB and Mix.2 (25). Smad 4 translocates the signal complex into the nucleus, and Smad 6 and 7 act as inhibitory factors for the signal transduction through the Smad-dependent pathway (Fig. 1) $(25,29)$.

Smad-independent pathway. There is greater affinity between BMPs and type I receptors compared with type II receptors (25). Thus, BMP ligands are also able to bind to ALK3 or ALK6, and then recruit BMPR 2 into a hetero-oligomeric complex; this activates the Smad-independent pathway (25-27). The X-linked inhibitor of apoptosis protein acts as an adaptor protein to relay signalling from the type I receptor to downstream TGF $\beta$-activated binding protein, leading to activation of TGF $\beta$-activated tyrosine kinase 1 (30-32). BMP-4 can induce apoptosis through this Smad-independent pathway, in which $\mathrm{p} 38$, a mitogen-activated protein kinase (MAPK) $(26,33,34)$, Jun N-terminal kinases (JNKs), NF- $\kappa \mathrm{B}$ and Nemo-like kinase (35-37) are involved (Fig. 1).
Regulatory factors of BMP signalling. Regulation of BMP pathway activity can be mediated through several positive or negative modulators, which may be extracellular when ligands bind to receptors, intracellular when the signal is being relayed or intranuclear when modulating R-Smad-mediated regulation of BMP-responsive genes (25).

Extracellular regulatory factors. Secreted extracellular BMP antagonists, including Noggin, Gremlin, Chordin and twisted gastrulation-1, provide important regulation (25). These antagonists exert their regulatory role in two ways. BMP antagonists can prevent BMPs from the binding to receptors by binding directly to BMP ligands, thus preventing ligand-receptor interaction (Fig. 1) (25). Antagonists are often target genes of BMP signalling; thus, a negative regulatory feedback loop is formed to ensure signalling homeostasis (38). For example, it has been shown that BMP-2, 4 and 6 can induce Noggin expression in osteoblasts (39). By upregulating their antagonist expression, the BMPs are thus able to regulate their activity (39).

Other factors also regulate BMP signalling extracellularly, such as pseudoreceptors and co-receptors. For example, BMP and activin membrane-bound inhibitor (BAMBI) acts as a pseudoreceptor by competitively binding to the BMP ligands with its extracellular domain, which shares high homology with type I receptor; however, as it lacks intracellular domains, the signal is not transduced (40). Similar to the BMP antagonists, BAMBI can be induced by BMP-4 in mouse embryonic fibroblasts, leading to negative feedback regulation of BMP signalling (41).

In addition to these negative regulators, there are positive regulators for the BMP pathway, such as co-receptors, which enhance BMP signalling $(25,42-44)$. Previous studies showed that repulsive guidance molecules (RGMs; including RGMA, RGMB and RGMC) are co-receptors for BMP-2 and BMP-4. RGMB, also known as Dragon, can bind directly to BMP-2 and BMP-4, enhancing signalling (42-44).

Intracellular regulatory factors. Among the intracellular regulatory factors, I-Smads can prevent R-Smads from the binding to the activated type I receptors, as well as blocking the recruitment of Smad 4 to the activated R-Smads (Fig. 1). For example, it has been reported that Smad 6 and 7 can weaken BMP signalling by preventing Smad 1 and 5 activation by the type I receptor, and that they can also prevent the interaction between Smad 1/5 and Smad 4 (45). In addition, BMP signalling can induce Smad 6/7 expression, enhancing the negative regulation of further BMP signalling $(46,47)$. Secondly, as Smads exhibit low binding affinity to the Smad binding elements (SBEs) of target genes, other transcription factors are required for the regulation of BMP-responsive genes, such as Smad interacting protein-1 (48), activating transcription factor (ATF)2 (49), p53 (50), Runx (51) and Forkhead box HI (FOXHI); FOXHI can specifically help recruit activated Smad 2/4 to the promoters of target genes in TGF $\beta$ signalling (52). Additionally, the interactions between certain transcriptional co-activators/repressors and the $\mathrm{MH} 2$ binding domain of Smad have been shown to regulate BMP. For example, P300 and CREB-binding protein interactions with Smads can increase the transcription of target genes by making the transcriptional machinery more accessible (53). However, 


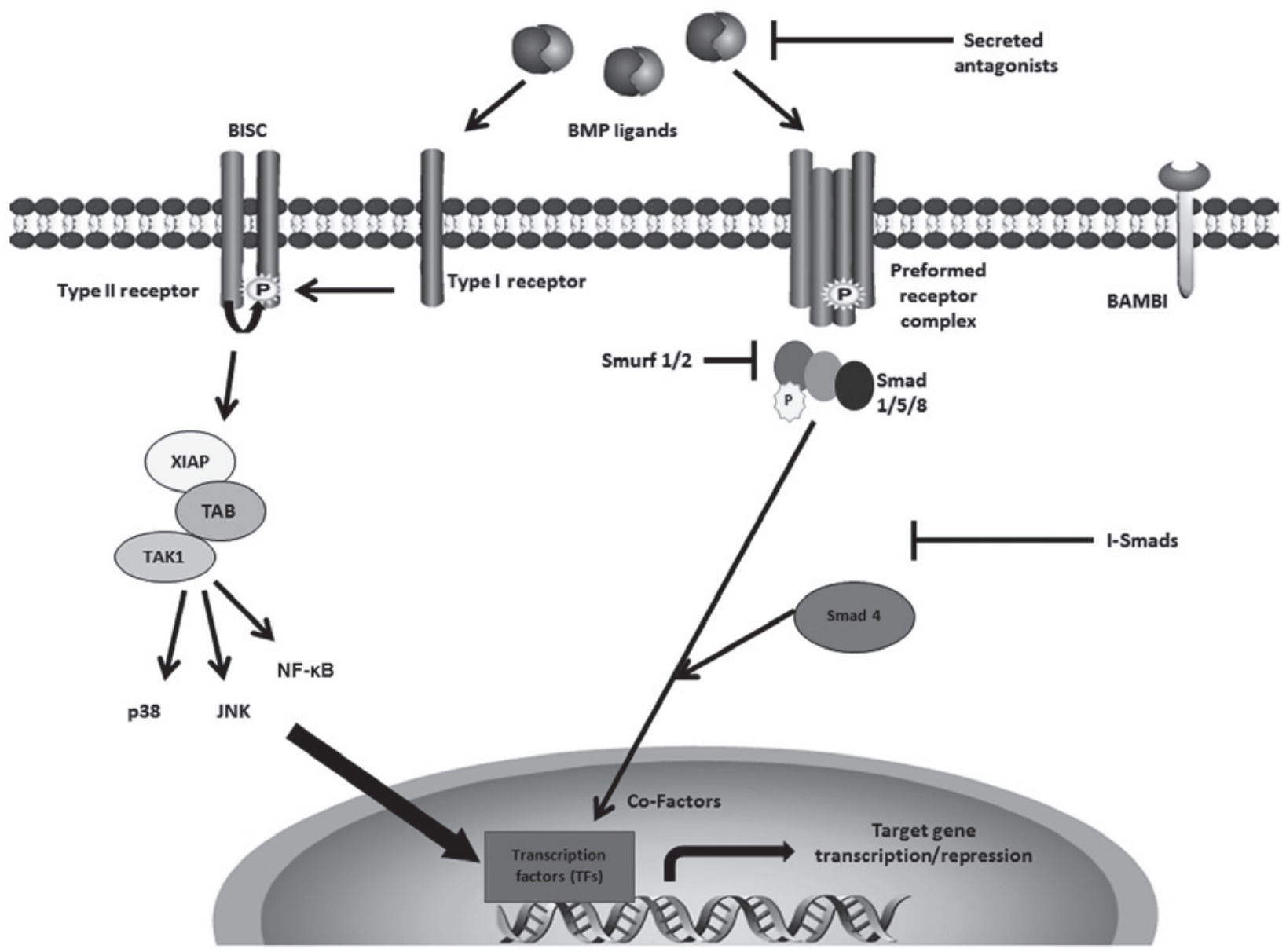

Figure 1. Smad-dependent and -independent signal transduction of BMPs. BMP signalling is mediated via oligomeric complexes of type I and type II receptors. With canonical Smad-dependent signalling, the BMP ligand binds a preformed oligomeric complex, resulting in the phosphorylation of the glycine-serine region of the type I receptor, and subsequent recruitment and phosphorylation of the pathway-restricted Smad 1/5/8 complex. With the common mediator Smad 4, Smad $1 / 5 / 8$ is able to translocate to the nucleus and form regulatory complexes with co-factors/transcription factors that will ultimately affect transcription of target genes. This may include upregulation of regulatory elements within the signalling pathway such as the I-Smads (Smad 6 and 7), which provide homeostatic negative feedback regulation. Other negative regulators include secreted BMP antagonists, including Noggin, Chordin and Gremlin, which bind the BMP ligands and prevent receptor interaction, and BAMBI, which is a type I pseudoreceptor that can sequester BMP ligands. In addition, Smurf1/2 can directly induce Smad 1/5/8 ubiquitination and degradation. BMP ligands can also induce other cell signalling pathways via the non-canonical Smad independent signalling pathway. This occurs when the BMP ligand initially binds type I receptors and then recruits the type II receptor into the BISC. This initiates a cascade of adaptor proteins and linking molecules, such as XIAP, TAB and TAK1, with resultant activation of several distinct mitogen-activated protein kinase pathways. This figure was prepared using pathway builder tools from www.proteinlounge.com. BAMBI, BMP and activin membrane-bound inhibitor; BMP, bone morphogenic protein; BISC, BMP-induced signalling complex; I-Smad, inhibitory Smad; JNK, Jun N-terminal kinase; P, phosphorylation; Smurf, Smad ubiquitination regulatory factor; TAB, TGF $\beta$-activated binding protein; TAK1, TGF $\beta$-activated tyrosine kinase I; TGF $\beta$, transforming growth factor $\beta$; XIAP, X-linked inhibitor of apoptosis protein.

transcriptional co-repressors, including Ski and Ski related novel gene, ecotropic viral integration site-1, TG interacting factor (TGIF)1 and TGIF2, prevent Smad 3/4 from binding to the SBE of BMP-responsive genes (54-57). Lastly, the BMP pathway can be influenced by Smad ubiquitination regulatory factor (Smurf)1/2, which induce degradation of Smads (Fig. 1) (58). The regulatory factors that co-ordinate BMP signal transduction have been summarised previously (59).

\section{Interaction between BMP and other signalling pathways}

BMP and its signalling pathways are not isolated in normal tissues and tumours, but are intricately linked to numerous other growth factors, such as the epidermal growth factor (EGF) receptor (EGFR) (16), receptor tyrosine kinase (RTK)/MAPK (17-19), PI3K/Akt (20-24,60), Wnt (61-65) and hepatocyte growth factor (HGF)/Met pathway $(66,67)$; together, they form a vast network that regulates various biological functions. There are multiple levels where cross-talk can occur: By regulating ligands, antagonists, receptors, or signalling components expression or activities; by direct interactions with Smads or other signalling components (68); and by incorporating into transcription complexes that alter target gene expression (69-71).

Interaction between BMP and EGFR signalling. EGFR is regarded as an oncogenic factor belonging to the ErbB RTK family, and is overexpressed in various types of cancer, such as colorectal cancer, non-small cell lung cancer, gastric cancer, esophagogastric cancer and pancreatic cancer (72). Intracellular signalling of EGFR is generally mediated through PI3K/Akt, Ras/MAPK and the phospholipase C/protein kinase C (PKC) signalling cascades (73), which are critical for cell proliferation, differentiation, motility and survival (74). 


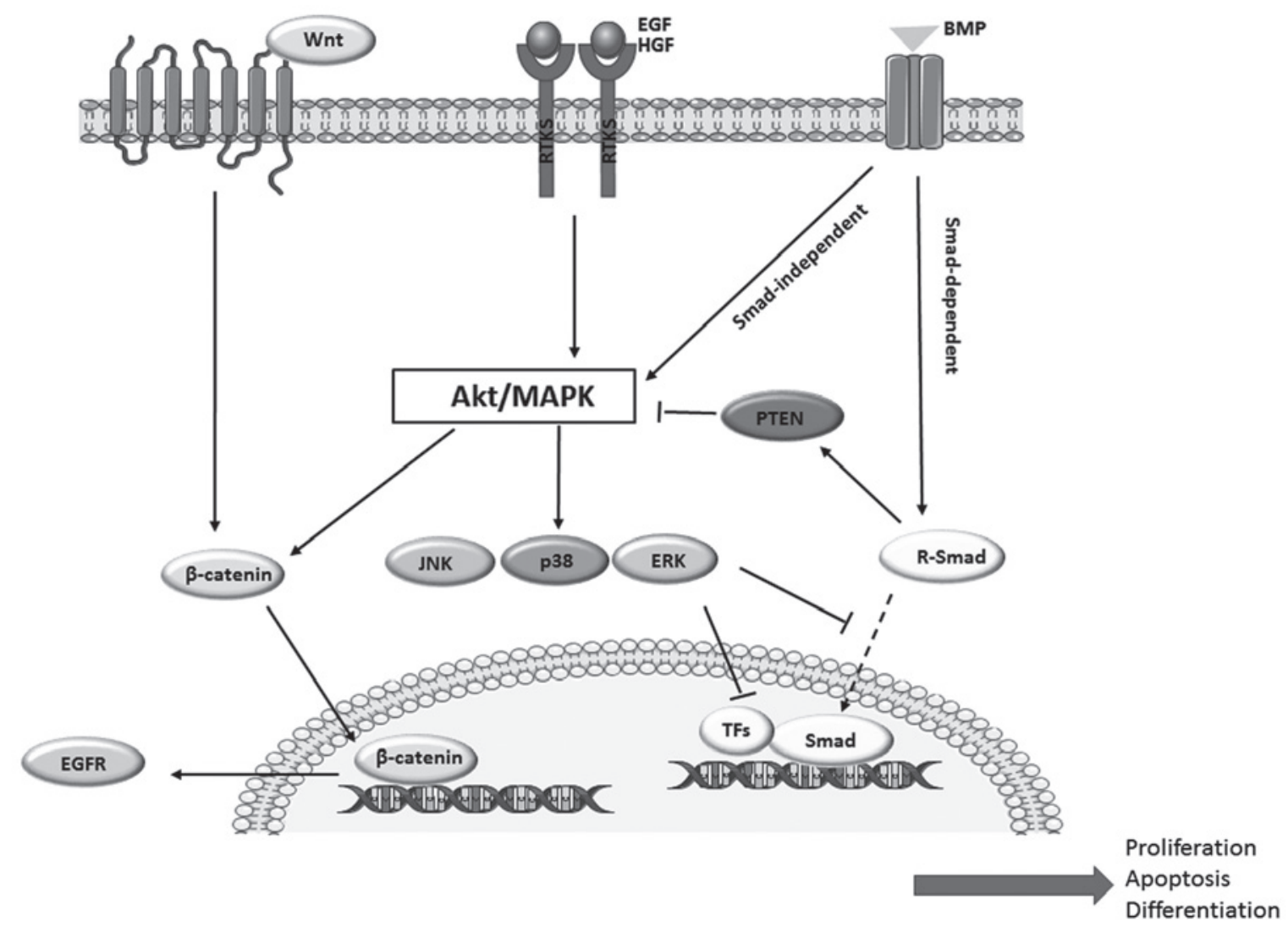

Figure 2. Crosstalk between RTKs and the BMP signalling pathway. BMP activates Smad-dependent pathways through the phosphorylation of R-Smads by its type I receptor, and regulates the translocation of R-Smad and common mediator Smad. The translocation of Smad can be inhibited by ERK signalling. BMP and RTKs also regulate cellular responses through Smad-independent pathways with the involvement of RTK/mitogen-activated protein kinase, RTK/Akt and RTK/Wnt signalling. This figure was prepared using graphical materials from Servier Medical Art (http://servier.com). BMP, bone morphogenic protein; EGFR, epidermal growth factor receptor; JNK, Jun N-terminal kinase; R-Smad, regulatory Smad; RTK, receptor tyrosine kinase; TF, transcription factor.

Studies have shown that EGF can directly influence the expression of BMPs. For example, BMP-6 in MCF-7 breast cancer cells can be induced by EGF/EGFR signalling (16). The function of the BMP pathway can also be indirectly regulated intracellularly by signalling molecules downstream of the EGFR, including the RTK/MAPK pathway and the PI3K/Akt pathway.

$B M P$ and the RTK/MAPK pathway. RTK/MAPK signalling can regulate BMP function. Secretion of additional growth factors and cytokines which promote EMT and cell invasion can often result from the interaction between TGF $\beta$ and RTK/MAPK pathways (17-19,75,76). ERK has been shown to upregulate Smad 3 in epithelial and smooth muscle cells (77).

The linking region of Smad proteins plays a vital role in interactions between BMP signalling and RTK/MAPK pathways. For example, activation of oncogene Ras can restrict BMP-induced Smad 2/3 signalling, including translocation into the nucleus and binding to the target genes (78). RTK-induced activation of ERK or JNK can phosphorylate endogenous Smad 2/3 (75,76). Furthermore, Thr178, Ser203 and Ser207 within the linker region of Smad 3 can be phosphorylated by ERK, leading to suppression of nuclear translocation (79). However, in MCF10CA1h breast cancer cells, p38 MAPK-induced phosphorylation of the Ser203 and Ser207 residues of Smad 3 facilitate, rather than inhibit, BMP-induced growth inhibition (80). These results suggest that varied phosphorylation of the Smad 2/3 linker region can lead to different results depending on the specific kinase, as well as the specificity of phosphorylation sites in intracellular events downstream of those activated receptors (81).

ERK1/2 can also prevent the nuclear translocation of Smad 1/5 via similar phosphorylation of their linker region (81). Furthermore, the oncogene Ras can reduce the stability of Smad 4 via the ERK pathway (82). Conversely, activation of JNK and p38 can target a tumour-associated mutant Smad 4, leading to degradation of the protein (83). There is suggested involvement of ERK, JNK and p38 in the regulation of Smad 7 transcription (84-86).

In addition to the above direct effects, MAPKs can also indirectly affect the activity of the BMP pathway by phosphorylating other nuclear transcription factors involved in the pathway within the nucleus, including Jun and activator protein-1 proteins such as Maf, Fos and ATFs (87). For example, p38 MAPK can activate ATF1, ATF2 and ATF3, which bind Smads and participate in BMP-regulated activities (Fig. 2) (49,88-91).

BMP and the PI3K/Akt pathway. Various studies have shown that BMP signalling can regulate the PI3K/Akt pathway, affecting cell proliferation (20), invasion (21), migration (22), EMT $(92,93)$ and differentiation (94). This regulation can be achieved via activation of Smad-independent pathways $(23,24)$. Secondly, BMP signalling can regulate the 
PI3K/Akt pathway by altering the transcriptional level or activity of PTEN. For example, Beck and Carethers (60) showed that long-term exposure to BMP-2 downregulated PTEN in Smad 4-null colon cancer cells through the Ras/ERK pathway. Previous studies showed BMP signalling could enhance PTEN activity $(95,96)$. Conversely, in hematopoietic cells, BMP/Smad signalling can also suppress Akt activity via regulation of $\mathrm{SH} 2$ domain-containing 5' inositol phosphatase, which is a lipid phosphatase targeting phosphatidylinositol (3,4,5)-trisphosphate (Fig. 2) (97). Furthermore, $\mathrm{PI} 3 \mathrm{~K} / \mathrm{Akt}$ activation could promote the nuclear translocation of $\beta$-catenin $(98,99)$, increase transcription of EGFR and enhance EGFR signalling, forming a vicious circle comprising Akt, $\beta$-catenin and EGFR (Fig. 2).

BMP and the HGF/Met pathway. HGF is a regulator of cell motility, mitogenesis, morphogenesis and angiogenesis (100). HGF and its receptor c-Met are actively involved in tumour growth, invasion and metastasis (101). Targeting HGF/c-Met can inhibit the proliferation and invasion of cancer cells both in vitro and in vivo (101-106).

HGF is mainly produced by fibroblasts and stored in adipose cells (101). Both solid tumour cells and leukaemia cells have also been reported to produce HGF (107-110). For example, overexpression of HGF in prostate cancer has been associated with disease progression and androgen independence $(111,112)$.

There have been studies reporting an interaction between the BMP and HGF signalling. For example, Ye et al $(29,100)$ reported that BMP-7, BMPRIB and BMPR2 were upregulated in prostate cancer cells. Imai et al (66) also showed that HGF was able to regulate BMP receptors. A recent study showed that HGF promoted bone regeneration and the formation of new blood vasculature via upregulation of BMP-2 (67). However, the exact transcriptional regulatory mechanism remains unclear. Further investigation is required to determine how the interaction between BMP and HGF is involved in bone metastasis.

BMP and Wnt pathway. The Wnt signalling pathway is essential for cell proliferation, differentiation, migration, survival and other processes (68). Dysregulated Wnt signalling has been observed in colorectal cancer and leukaemia (113). The Wnt signalling pathway has been extensively studied and reviewed, and comprises canonical and non-canonical pathways, the latter of which include the planar cell polarity pathway and Wnt/calcium pathway (61).

In terms of the canonical pathway, upon binding with Wnt ligand, Frizzled receptors and the transmembrane protein low-density lipoprotein receptor-related protein 5/6 induce intracellular signalling and regulation of responsive genes through $\beta$-catenin (68). Outside of Wnt signalling, $\beta$-catenin is generally degraded by a protein complex which comprises adenomatous polyposis coli, Axin, casein kinase $1 \alpha$ and glycogen synthase kinase $3 \beta$ (GSK-3 $\beta$ ) (61). Degradation of $\beta$-catenin is prevented when GSK-3 $\beta$ and Axin are recruited via the Wnt signalling, leading to nuclear translocation and regulation of Wnt target genes (62-65). Crosstalk between the BMP pathway and the Wnt pathway can occur at multiple levels.
Reciprocal regulation of the expression of pathway ligands and antagonists. The Wnt signalling pathway can regulate the expression of BMPs, BMP co-receptors or their antagonists during embryonic development and in cancerous cells (81). Conversely, BMP-2 and BMP-4 are able to regulate the expression of certain Wnt proteins, such as Wnt-7c (89) and Wnt-8 (114).

Direct interaction between key components in the cytoplasm and nucleus. GSK-3 $\beta$ can regulate the BMP pathway by phosphorylating the linker region of Smad $(68,115-117)$. In the absence of upstream signalling, Smad 3 can be degraded by GSK-3 $\beta$ when it is recruited into a protein complex comprising Axin and GSK-3 $\beta(68,116)$. GSK-3 $\beta$ can also target the BMP-activated R-Smads, Smad 1 or Smad 3, leading to their degradation and the inhibition of downstream signalling (68). However, the regulation of Smad by GSK-3 $\beta$ can be prevented by Wnt signalling, leading to a stabilisation of Smad proteins (Fig. 3) (68).

Certain molecules in the BMP pathway are also involved in the regulation of Wnt signalling, such as Smurf1 (118) and Smurf2 (119). Smurf1 and Smurf2 are key molecules in the degradation of Axin, which may consequently disrupt the Wnt signalling. In addition, Smad 3 is also involved in the nuclear translocation of $\beta$-catenin (Fig. 3) (120).

Convergence at transcription complexes. In response to Wnt signalling and BMP signalling, activated transcriptional factors such as Smads, T cell factor/lymphoid enhancer-binding factor 1 and cofactors can co-ordinate the regulation of target genes, including gastrin Xtwin, Msh homeobox (Msx)2 and T-box transcription factor 6 (Fig. 3) (69-71).

Other pathways. In addition to the above, there are also interactions between the BMP pathway and other pathways, including the Hedgehog (Hh) pathway (121-124), Notch pathway (125-128), Janus kinase/STAT pathway (129-133) and $\mathrm{NF}-\kappa \mathrm{B}$ pathway (134-136). For example, Smads can co-ordinate $\mathrm{Hh}$ signalling through regulation of GLI (124). BMP and Notch orchestrate cell differentiation and proliferation by targeting common genes (125). BMP and NF- $\mathrm{B}$ act against each other in co-ordinating immune responses (133).

Overall, the BMP pathway is integrated into various signalling networks through these interactions, thus orchestrating cellular events in tumourigenesis and the progression of malignancies.

\section{BMP and tumour-associated angiogenesis}

Angiogenesis is essential for the tumour growth and haematological dissemination of cancer cells $(137,138)$. There are two stages in the progression of neovascularisation, an activation phase and a late phase (25). ALK1 and downstream Smad signalling are involved in the activation phase, whilst ALK5 and Smad 2/3 promote maturation of the newly formed vasculature at the late phase (139). It has been shown that BMPs can affect angiogenesis via both direct and indirect routes.

Direct regulation of angiogenesis. BMP-2, 4, 6 and 7, and growth differentiation factor (GDF)-5 can directly 


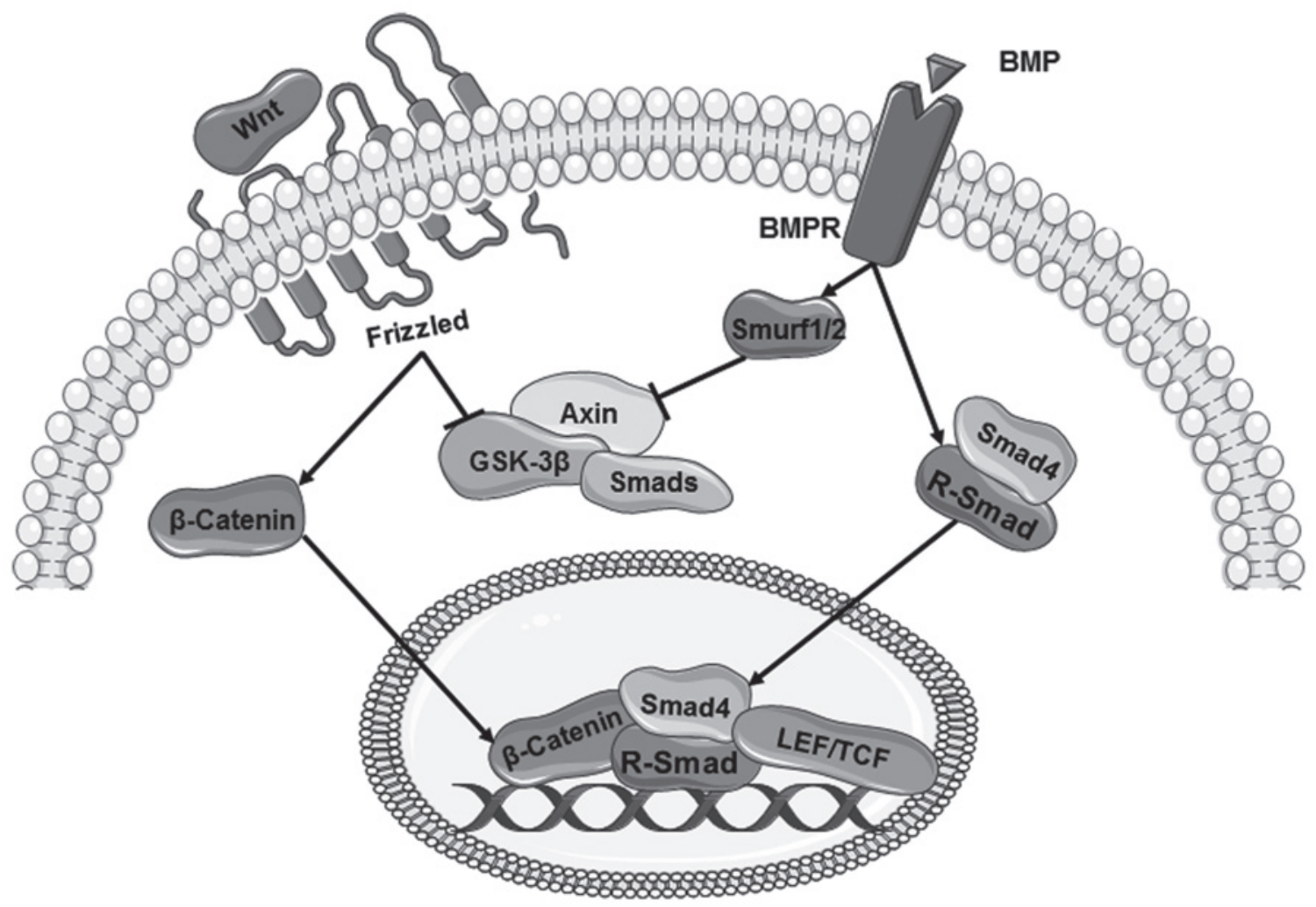

Figure 3. Interactions between BMPs and Wnt/ $\beta$-catenin signalling. This figure was prepared using graphical materials from Servier Medical Art (http://servier.

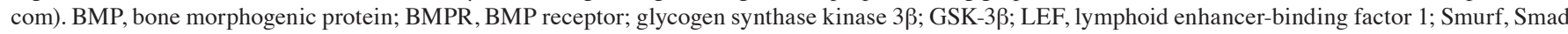
ubiquitination regulatory factor; TCF, T cell factor.

regulate the proliferation and migration of vascular endothelial cells (140-143). For instance, in a chorioallantoic membrane assay, GDF-5 promotes angiogenesis (140). BMP-2 exhibits pro-angiogenic effect in both in vivo tumour models (144) and in vitro functional assays of vascular endothelial cells (145). In addition to direct effects on vascular endothelial cells, BMP-2 can also promote the motility of vascular smooth muscle cells (146). BMP-4 and BMP-7 can also promote the migration of vascular smooth muscle cell $(147,148)$. Of note, BMP-9/-10 elicit concentration-dependent biphasic effects on angiogenesis, specifically an inhibitory effect at high concentrations and a promotive effect at lower concentrations (Fig. 4) (149).

BMP receptors are important mediators of the pro-angiogenic BMP signal. For example, vascular endothelial cells exhibited higher expression of BMPRIB and BMPR2 in an in vitro tubule formation assay (150).

Studies have shown that distinct Smad pathways may play opposing roles in angiogenesis, and that the same Smad may also play different roles in angiogenesis for distinct types of tissues. For example, Smad 3 mediates an upregulation of vascular endothelial growth factor A (VEGFA), whereas Smad 2 is involved in the regulation of thrombospondin-1 in rat proximal tubular cells NRK52E (151). However, Smad 3-mediated repression of VEGF impaired angiogenesis induced by the gastric cancer cell line SNU484 (152).

As antagonists of BMPs, Noggin and Gremlin are also key regulators of tumour angiogenesis. Noggin can prevent BMP-7-induced angiogenesis (153); conversely, Gremlin can promote angiogenesis by directly targeting VEGF receptors (154).
Indirect regulation of angiogenesis. In addition to these direct effects, BMPs can also indirectly promote angiogenesis via upregulation of VEGF in other cells, such as cancer cells and stromal cells (138). For example, BMP-7 is actively involved in the bone metastasis of prostate cancer cells via regulation of VEGF (153), in addition to its direct regulation of VEGF receptor in vascular endothelial cells (155). BMP-2 promotes tumour-associated angiogenesis via upregulation of VEGF mediated by the $\mathrm{p} 38$ pathway in breast cancer (156). In contrast to most BMPs, BMP-9 elicits inhibition of the proliferation of vascular endothelial cells through ALK-1 (157). In addition, BMPs can indirectly induce VEGF (158), basic fibroblast growth factor and TGF $\beta 1$ in stromal cells (Fig. 4) (159).

\section{BMPs and EMT}

EMT is pivotal for the carcinogenesis and aggressive traits acquired by cancer cells during disease progression and metastasis $(160,161)$. BMP-regulated EMT has been implicated in various studies regarding organ development $(162,163)$ and cancer (164-167). In vitro, BMP-4 induces EMT-like properties in mammary epithelial cells, transforming them to express an invasive phenotype (165). BMP-2 can enhance the invasion and migration of breast cancer cells $(168,169)$, and the effect may be mediated by the upregulation of ID-1 (170). However, there are other BMPs that play opposing role, such as BMP-7, which was not able to regulate the EMT in a murine mammary epithelial cell line, NMuMG (166). BMP-7 can prevent EMT in breast cancer cells by decreasing vimentin (171). BMP-6 can impair the metastatic capacity of breast cancer cells by 


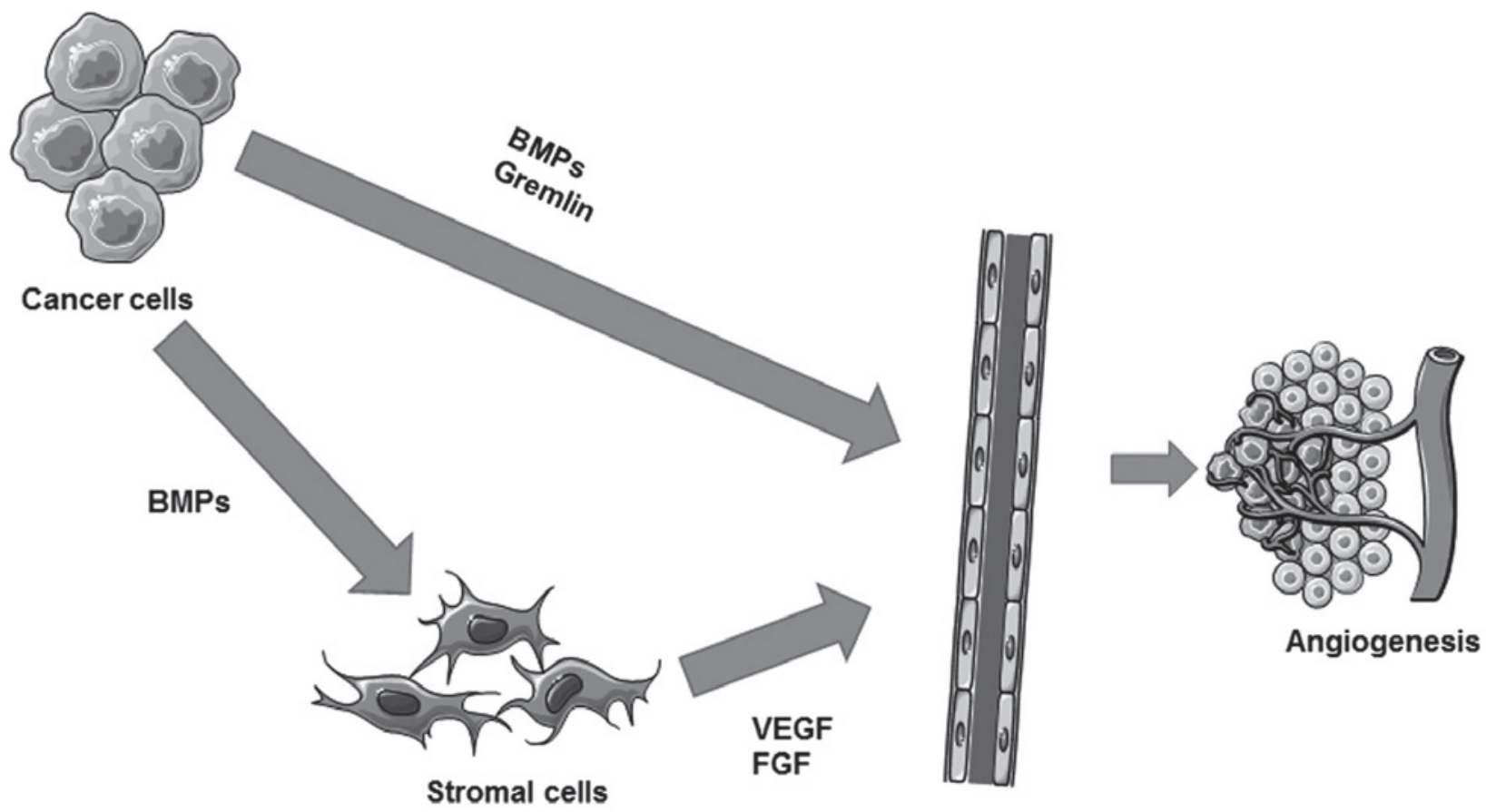

Figure 4. BMPs regulate tumour-associated angiogenesis via multiple mechanisms. This figure was prepared using graphic materials from Servier Medical Art (http://servier.com). BMP, bone morphogenic protein; FGF, fibroblast growth factor; VEGF, vascular endothelial growth factor.

repressing miR-21 and zinc finger E-box-binding homeobox 1 (ZEB1), which subsequently leads to upregulation of E-cadherin (167,172,173). Both Smad-dependent (174-176) and Smad-independent pathways $(178,179)$ have been observed to be involved in BMP-regulated EMT. For example, BMP signalling could directly activate the transcription of Snail, Twist1 and Msx1/2 (174-176). Regarding the Smad-independent pathway, BMP-2 could induce EMT via the PI3K/Akt pathway $(177,178)$. Furthermore, BMPs could influence tumour invasion by regulating MMPs, extracellular matrix components, cytokines, and immune or inflammatory cells in the tumour microenvironment (158). BMP-4-regulated MMP3 and interleukin-6 are involved in the fibroblast-stimulated invasion of breast cancer cells (179).

\section{BMP-co-ordinated interaction between cancer cells and other cellular/non-cellular parts within the tumour}

BMPs play an important role in co-ordinating the interactions between cancer cells and the surrounding environment in tumourigenesis and disease progression $(158,180)$. For example, BMP released from tumour-associated stromal cells can induce EMT in cancer cells via the induction of ZEB1 (158). Meanwhile, BMP-2 and BMP-4 secreted by breast cancer cells can reciprocally act on stromal cells to synthesise more tenascin-W and MMPs, which can further enhance their invasiveness $(158,180)$. However, BMP-6, BMP-10 and BMP-15 are able to inhibit the invasion and motility of cancer cells, while BMP-4 exhibits biphasic effects (158).

A number of cells located within tissues are embedded in the ECM, which comprises collagens, proteoglycans and adhesion proteins (181). The ECM is very versatile and undergoes remodelling during tumour development $(181,182)$. Within the tumour stroma, both the cancer cells and cancer-associated fibroblasts can remodel the ECM (182). Growth factors and cytokines will be released to the ECM, thus contributing to the tumour-supporting microenvironment (182), which is actively involved in disease progression and metastasis. Studies have shown that the remodelling of ECM can be regulated by BMP $(183,184)$. For example, secretion of collagen type I and type III from hepatic stellate cells can be reduced by recombinant human BMP-7 via inhibition of TGF $\beta 1$ and its signalling (183). Another study showed that Type I and type III collagen synthesis was significantly up-regulated following BMP-2 treatment in human scleral fibroblasts (184).

The CCN family, including CCN1-6, are a family of matricellular proteins (185-187). CCN proteins are regulators of cell proliferation (188-190), adhesion (191), migration (192,193), survival (194), apoptosis (195), angiogenesis (196) and inflammation $(197,198)$ in numerous types of cells, including vascular endothelial cells and other cells within the stroma.

$\mathrm{CCN}$ proteins can directly interact with BMPs; for example, binding of CCN2 to BMP-4 prevents its interaction with BMP receptors, thus inhibiting BMP-induced cell proliferation (199). In addition, there have been reported interactions between CCN3 and BMP-2 (200), CCN4 and BMP-2 (201), and CCN6 and BMP-4 (202). CCN proteins may act as both antagonists and agonists for BMP signalling, depending on the expression profile of related molecules $(189,203,204)$. CCN2 promotes the proliferation of chondrocytes via ERK and JNK signalling pathways, and induces differentiation via p38 $(189,203)$. BMP-2 can suppress the phosphorylation of ERK1/2, which impairs CCN2-promoted proliferation (204). Similarly, CCN2 can abolish BMP-2-promoted cell proliferation by inhibiting Smad-dependent and independent pathways (205).

In addition, studies have shown that certain non-coding RNAs play roles in the interaction between the tumour microenvironment and BMPs. For example, Xiao et al (206) 


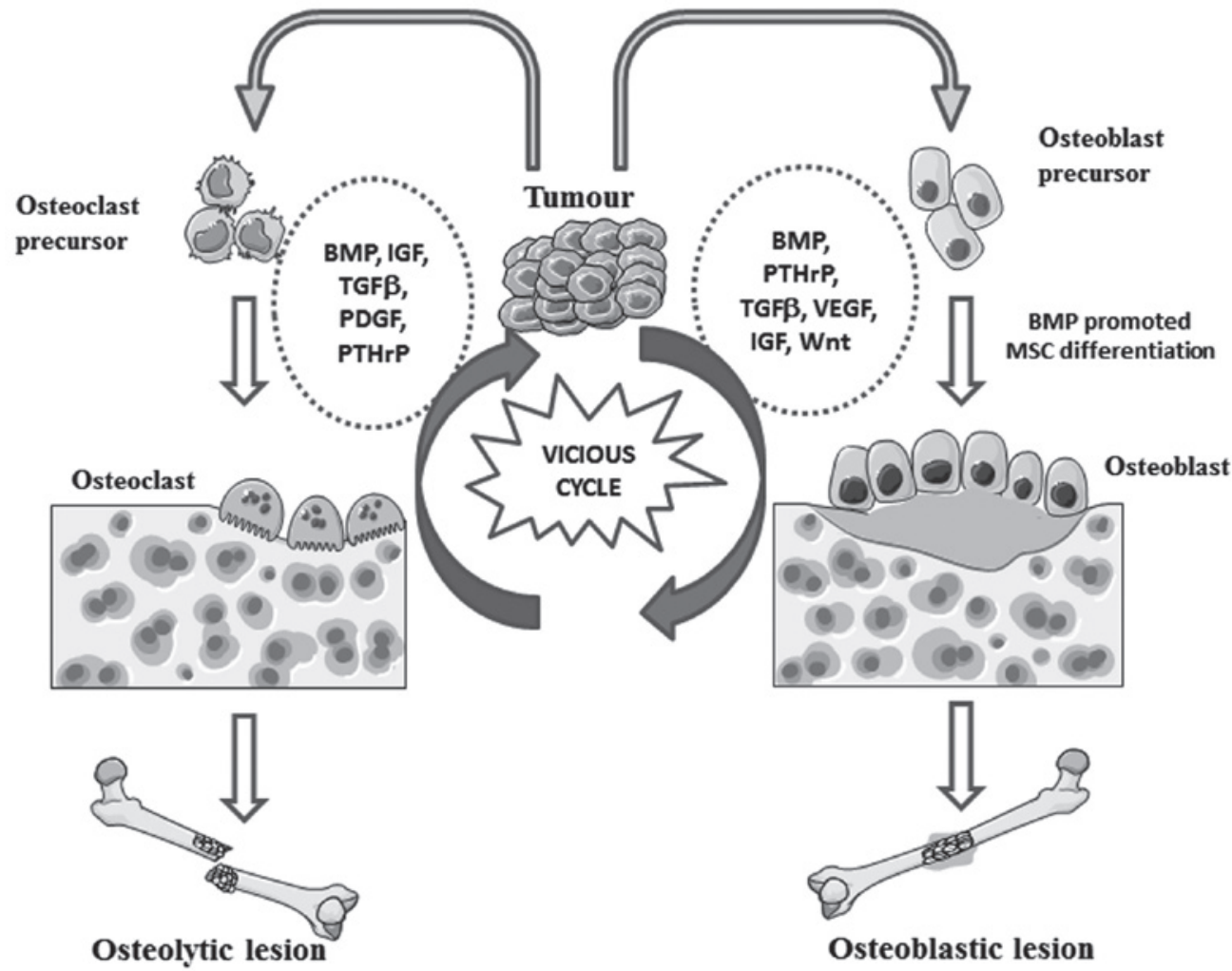

Figure 5. BMPs actively engage in a vicious cycle during the development of bone metastasis. Secretion of BMPs and other cytokines by cancer cells within the bone niche can influence the differentiation of mesenchymal stem cells into osteoclasts and/or osteoblasts, and also regulate the cellular behaviour of osteoclasts and osteoblasts. This results in bone deposition or osteolysis, and facilitates secretion of factors that then further support the establishment of tumour cells within the niche, thus propagating a vicious cycle in bone metastasis. This figure was prepared using graphic materials from Servier Medical Art (http://servier. com). BMP, bone morphogenic protein; IGF, insulin-like growth factor; PDGF, platelet-derived growth factor; PTHrP, parathyroid hormone-related protein; TGF $\beta$, transforming growth factor $\beta$; VEGF, vascular endothelial growth factor.

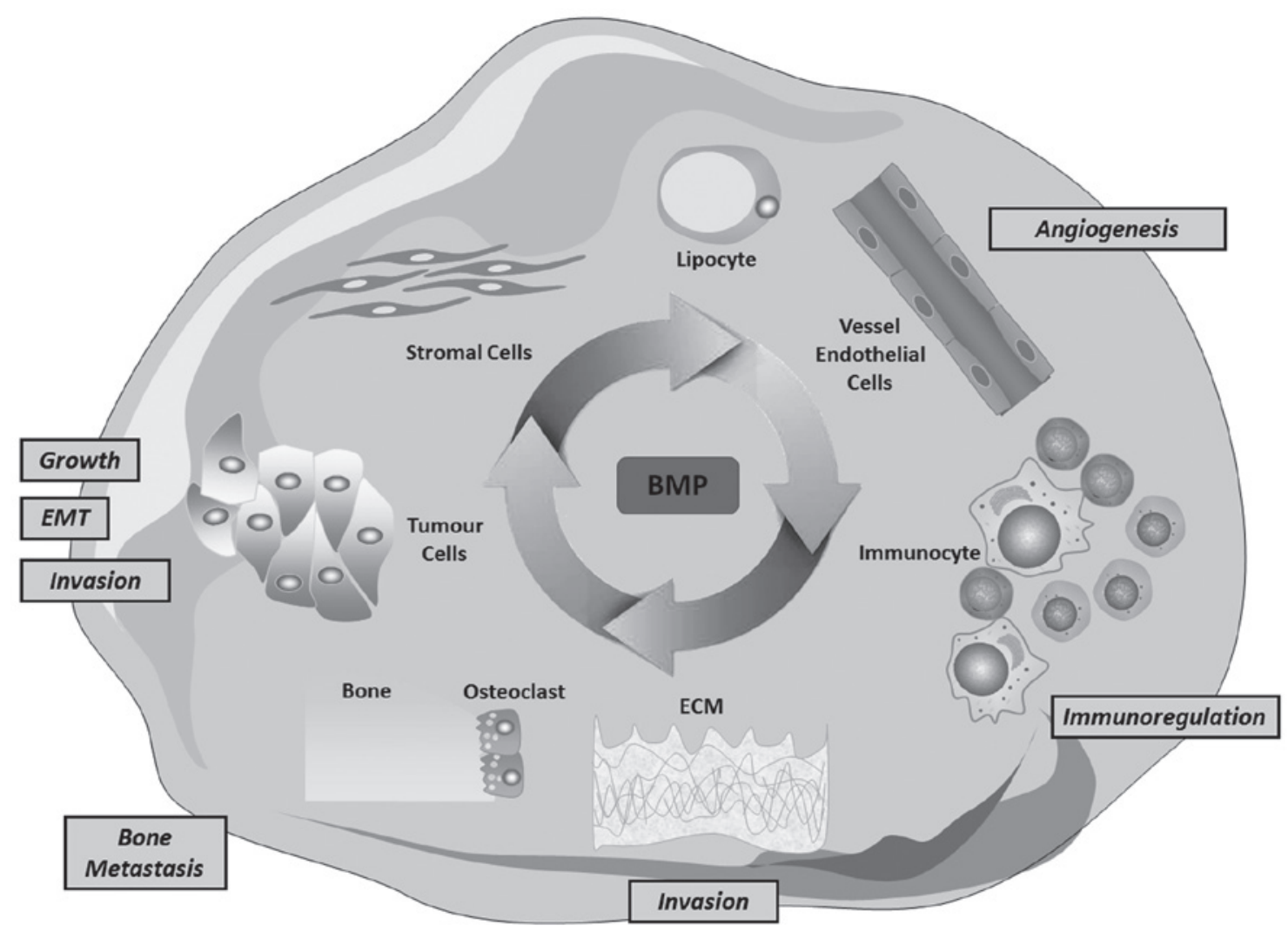

Figure 6. BMPs in the tumour microenvironment. This figure was generated using ScienceSlides graphics from Visiscience (https://www.visiscience.com/). BMP, bone morphogenic protein; ECM, extracellular matrix; EMT, epithelial to mesenchymal transition. 
Table I. Related clinical trials.

\begin{tabular}{|c|c|c|c|c|}
\hline Target & Specific agent and effect & $\begin{array}{l}\text { Agent(s) used in } \\
\text { clinical trial }\end{array}$ & Tumour type & $\begin{array}{l}\text { Clinical trial number } \\
\text { and phase }\end{array}$ \\
\hline \multirow[t]{25}{*}{ CD105 } & $\begin{array}{l}\text { TRC105, a novel antibody } \\
\text { targeting CD105 with }\end{array}$ & $\begin{array}{l}\text { TRC105 + Avastin }^{\circledR} \\
\text { (bevacizumab) }\end{array}$ & Kidney cancer & $\begin{array}{l}\text { NCT01727089/Phase 2B } \\
\text { randomised }\end{array}$ \\
\hline & & TRC105 & Prostate cancer & NCT01090765\%/Phase $1 \& 2$ \\
\hline & & TRC105 & Urothelial carcinoma & NCT01328574ª/Phase 2A \\
\hline & & $\begin{array}{l}\text { TRC105 + Nexavar }{ }^{\circledR} \\
\text { (sorafenib) }\end{array}$ & Liver cancer & NCT01306058 a/Phase 1B/2A \\
\hline & & TRC105 & Liver cancer & NCT01375569\%/Phase 2A \\
\hline & & TRC105 + Avastin & Glioblastoma & NCT01648348/Phase \\
\hline & & & & $1 \mathrm{~B} / 2 \mathrm{~B}$ randomised \\
\hline & & TRC105 + Avastin & Glioblastoma & NCT01564914a/Phase 2A \\
\hline & & TRC105 + Avastin & Choriocarcinoma & NCT02396511ª/Phase 2 \\
\hline & & TRC105 & Ovarian cancer & NCT01381861 a/Phase 2A \\
\hline & & $\begin{array}{l}\text { TRC105 + Xeloda }{ }^{\circledR} \\
\text { (capecitabine) }\end{array}$ & $\begin{array}{l}\text { Metastatic breast } \\
\text { tumours }\end{array}$ & NCT01326481 a/Phase 1B \\
\hline & & TRC105 + Inlyta ${ }^{\circledR}$ (axinitib) & $\begin{array}{l}\text { Advanced renal cell } \\
\text { cancer }\end{array}$ & $\begin{array}{l}\text { NCT01806064 } / \text { Phase } 1 \mathrm{~B} / 2 \mathrm{~B} \\
\text { randomised }\end{array}$ \\
\hline & & $\begin{array}{l}\text { TRC105 + Votrient }{ }^{\circledR} \\
\text { (pazopanib) }\end{array}$ & $\begin{array}{l}\text { Advanced soft tissue } \\
\text { sarcoma }\end{array}$ & NCT01975519b/Phase 1B/2A \\
\hline & & TRC105 + Avastin & Advanced solid tumours & NCT01332721 a/Phase 1B \\
\hline & & $\begin{array}{l}\text { TRC105 + paclitaxel/ } \\
\text { carboplatin + bevacizumab }\end{array}$ & $\begin{array}{l}\text { Non-small cell lung } \\
\text { cancer }\end{array}$ & NCT03780010/Phase 1 \\
\hline & & TRC105 + bevacizumab & $\begin{array}{l}\text { Refractory gestational } \\
\text { trophoblastic neoplasia }\end{array}$ & NCT02664961/Terminated \\
\hline & & TRC105 + sorafenib & $\mathrm{HCC}$ & NCT02560779 b \\
\hline & & TRC105 + pazopanib & Angiosarcoma & NCT02979899 \\
\hline & & TRC105 + nivolumab & $\begin{array}{l}\text { Metastatic non-small } \\
\text { cell lung cancer }\end{array}$ & NCT03181308b \\
\hline & & $\begin{array}{l}\text { TRC105 + abiraterone + } \\
\text { enzalutamide }\end{array}$ & $\begin{array}{l}\text { Metastatic, castration- } \\
\text { resistant prostate cancer }\end{array}$ & NCT03418324 \\
\hline & & $\begin{array}{l}\text { TRC105 + paclitaxel/ } \\
\text { carboplatin + bevacizumab }\end{array}$ & $\begin{array}{l}\text { Stage } 4 \text { non-squamous } \\
\text { cell lung cancer }\end{array}$ & NCT02429843 \\
\hline & & TRC105 & Recurrent glioblastoma & NCT01778530/Terminated \\
\hline & & $\begin{array}{l}\text { Bevacizumab + axitinib + } \\
\text { pazopanib + capecitabine }\end{array}$ & Solid tumours & NCT02354612 ${ }^{\mathrm{c}}$ Phase $1 / 2$ \\
\hline & & $\begin{array}{l}\text { TRC105 + Femara } \\
\text { (letrozole) + Afinitor } \\
\text { (everolimus) }\end{array}$ & Breast cancer & NCT02520063c/Phase 1/2 \\
\hline & & TRC105 & $\begin{array}{l}\text { Advanced or metastatic } \\
\text { solid tumours }\end{array}$ & NCT00582985\%/Phase 1 \\
\hline \multirow[t]{5}{*}{ ALK1 } & $\begin{array}{l}\text { Dalantercept, a fusion } \\
\text { protein that binds to ALK1 } \\
\text { ligands and inhibits ALK1 }\end{array}$ & $\begin{array}{l}\text { Dalantercept (also known as } \\
\text { ACE-041) }\end{array}$ & $\begin{array}{l}\text { Ovarian cancer and } \\
\text { primary peritoneal } \\
\text { carcinoma }\end{array}$ & NCT01720173\%/Phase 2 \\
\hline & & Dalantercept + axitinib & $\begin{array}{l}\text { Advanced renal cell } \\
\text { carcinoma }\end{array}$ & NCT01727336\%/Phase 2 \\
\hline & & Dalantercept + sorafenib & Advanced adult HCC & NCT02024087a/Phase 1 and 2 \\
\hline & & ACE-041 & $\begin{array}{l}\text { Advanced solid tumours, } \\
\text { multiple myeloma }\end{array}$ & NCT00996957ª/Phase 1 \\
\hline & & Dalantercept & $\begin{array}{l}\text { Recurrent or persistent } \\
\text { endometrial cancer }\end{array}$ & NCT01642082a/Phase 2 \\
\hline
\end{tabular}


Table I. Continued.

\begin{tabular}{|c|c|c|c|c|}
\hline Target & Specific agent and effect & $\begin{array}{l}\text { Agent(s) used in } \\
\text { clinical trial }\end{array}$ & Tumour type & $\begin{array}{c}\text { Clinical trial number } \\
\text { and phase }\end{array}$ \\
\hline & \multirow{7}{*}{$\begin{array}{l}\text { PF-03446962, a novel } \\
\text { monoclonal antibody } \\
\text { targeting ALK1 with } \\
\text { reported dose-dependent } \\
\text { anti-angiogenic activity }\end{array}$} & Dalantercept & $\begin{array}{l}\text { Squamous cell } \\
\text { carcinoma of the } \\
\text { head and neck }\end{array}$ & NCT01458392a/Phase 2 \\
\hline & & PF-03446962 + regorafenib & Colorectal cancer & NCT02116894a/Phase 1 \\
\hline & & PF-03446962 & $\begin{array}{l}\text { Transitional cell } \\
\text { carcinoma of bladder }\end{array}$ & NCT01620970/Unknown \\
\hline & & PF-03446962 & $\mathrm{HCC}$ & NCT01911273/Terminated \\
\hline & & PF-03446962 & $\begin{array}{l}\text { Malignant pleural } \\
\text { mesothelioma }\end{array}$ & NCT01486368/Phase 2 \\
\hline & & PF-03446962 & Neoplasms & NCT01337050a/Phase 2 \\
\hline & & PF-03446962 & $\begin{array}{l}\text { Advanced solid } \\
\text { tumours }\end{array}$ & NCT00557856\%/Phase 2 \\
\hline
\end{tabular}

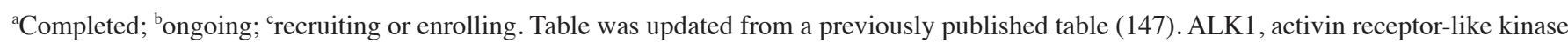
1; HCC, hepatocellular carcinoma.

reported that microRNA ( $\mathrm{miRNA} / \mathrm{miR})-885-3 \mathrm{p}$ inhibits the in vivo growth of HT-29 colon cells by disrupting angiogenesis via targeting BMPR1A, leading to a blockage of BMP signalling. Nishida et al (207) found that miR-17-92a and miR-106b-25 clusters were upregulated in colorectal cancer stromal tissues compared with normal stroma; putative targets of these miRNAs predicted by Target Scan were significantly downregulated in cancer stromal tissues, including TGF $\beta R 2$, Smad 2 and BMP family genes.

\section{BMP-related activities in bone metastasis}

BMPs enriched in bone matrix are the most potent factors to induce the formation of new bone (58). Numerous studies have reported that BMPs are expressed to varying degrees in a range of benign and malignant bone tumours, such as osteoid osteoma (208), fibrous dysplasia (209), giant-cell tumours (210) and osteosarcoma (211). BMP expression was detected in both human osteosarcoma cell lines $(212,213)$ and human osteosarcoma specimens $(214,215)$. Furthermore, differential expression of BMPs was evident in different histopathological subtypes (215). For example, Yoshikawa et al (215) found that high-grade osteosarcoma with a malignant fibre histiosarcoma-type pattern exhibited the strongest expression of BMP-2/4. Additionally Sulzbacher et al (216) reported that BMPs are expressed in osteosarcoma specimens, and their expression is related with osteosarcoma histopathological subtype; high expression of BMP-6 was detected in osteosarcomas with chondroblastic differentiation. Aside from this aberrant expression, little is known regarding the biological function of BMPs in bone tumour cells. Li et al (217) showed that BMP-9 inhibited tumour growth and migration by blocking the PI3K/AKT signalling pathway in an osteosarcoma cell line.

In bone metastatic tumours, BMPs can be synthesised by both cancer cells and osteoblasts (218). There is increasing evidence showing that BMPs are implicated in bone metastases of prostate and breast cancer $(156,219,220)$. BMPs are expressed in both primary prostate tumours and bone metastases with different phenotypic patterns. For example, BMP-7 and GDF-15 are reduced in or absent from primary prostate tumours, but overexpression of both molecules is evident in the bone metastases $(219,220)$. In contrast, BMP-6 is consistently expressed at high levels in both primary tumours and bone metastases of prostate cancer (138). The expression profiles of BMP in primary tumours and bone metastases reflects an adaptive phenotype acquired by the cancer cells during disease progression based upon requirements at different metastatic locations. Elevated expression of BMP in cancer cells is more likely to result in osteoblastic bone lesion by enhancing bone formation (138). In addition to BMP ligands, the BMP antagonist Noggin has been associated with the osteolytic bone lesions of prostate cancer in a murine model (221). Moreover, loss of Noggin can also enhance osteoblastic activity in bone metastasis (222).

BMPs released from cancer cells can regulate osteoblastic or osteoclastic activities in bone lesions, leading to bone formation or resorption. BMPs secreted by osteoblasts/osteoclasts or released from disrupted bone can reciprocally induce EMT in cancer cells, promoting the development of bone lesions (218). These interactions form a vicious cycle during the development of bone metastasis (Fig. 5). However, the exact machinery 
underlying the regulation of BMP signalling utilised by the cancer cells requires more intensive investigation.

In addition to direct stimulation, BMPs can also enhance the vicious cycle during bone metastasis via regulation of other factors. For example, osteoprotegerin can be upregulated by BMP-2 in PC-3 cells, acting as a pseudo-receptor for receptor activator of $N F-\kappa B$ (RANK) ligand (RANKL) to prevent RANKL/RANK-induced osteoclastogenesis (223). BMP-7 can enhance osteoblastic activity via upregulation of VEGF in cancer cells (59). As angiogenic factors, BMPs can also facilitate the formation of bone metastasis by promoting tumour-associated angiogenesis.

\section{Therapeutic potential and perspectives}

The role played by BMP signalling in cancer progression, metastasis and angiogenesis has raised interest in developing targeted therapies. ALK1 appears to be the most attractive target for preventing tumour-associated new vasculature. PF-03446962, a monoclonal antibody against ALK1 from Pfizer, has exhibited dose-dependent anti-angiogenic effects (224). ALK1-Fc, known as Dalantercept or ACE-041, which exhibits high binding affinity to BMP-9 and BMP-10, has demonstrated an inhibitory effect on angiogenesis and thus tumour growth (225). These anti-angiogenic therapies are currently being evaluated for their therapeutic potential in the treatment of advanced cancers and metastases in different clinical trials (Table I). In addition to ALK1, CD105, a co-receptor for BMP-9, has been targeted with a monoclonal antibody, TRC105, to prevent angiogenesis (226). In a recent analysis of BMP and BMP receptors in gastric cancer in our lab (227), it was shown that elevated expression levels of BMP receptors in GC were highly associated with tumour-associated angiogenesis and lymphangiogenesis, which facilitate the tumour growth, expansion and spread. However, BMP signalling is only part of the orchestrated signalling required for the formation of new vasculature in tumours, with interactions with other pro-angiogenic factors and pathways, such as HGF, VEGF and fibroblast growth factor, also involved (138). More targeted and specific therapeutic approaches to meet the requirements of each individual patient are expected when improved understanding of the exact underlying mechanisms has been obtained. Therefore, the side effects, adverse effects, and imbalances between BMPs and BMP antagonists should be comprehensively considered when they are evaluated as targets to prevent bone metastasis. Additionally, antibodies or small inhibitors targeting the BMP pathway may affect human bone formation during development and tissue repair. Relevant side effects should be considered in future clinical studies.

In contrast to the development of anti-angiogenic therapies, BMPs have been evaluated for their direct anti-cancer potential with caution. This is mainly as a result of their biphasic effects in both primary tumours and secondary tumours. Most BMPs elicit inhibition of proliferation while also acting as potent inducers of EMT through Smad signalling (2). In bone metastases, imbalanced BMP signalling may facilitate either osteoblastic or osteolytic lesions. None of these will likely result in a favourable outcome in patients with solid tumours (158). More intensive research is required to elucidate the precise role played by BMP signalling in more specific windows of malignancy.
BMPs play a role in tumorigenesis and disease progression, not only from the activation of BMP signalling pathways (25-28), but also from BMP-mediated crosstalk between tumour cells and local environments comprising vascular endothelial cells (140-143), fibroblasts, ECM $(183,184)$, osteoclasts and osteoblasts $(137,217,219)$. BMPs can directly induce angiogenesis by acting on vascular endothelial cells (140-141), and also indirectly promote the synthesis and secretion of pro-angiogenic factors in both cancer cells and stromal cells $(138,153)$. BMP-2 and BMP-4 secreted by breast cancer cells can facilitate their invasiveness via upregulation of tenascin-W and MMPs in adjacent fibroblasts $(158,180)$. BMPs can also alter the ECM by promoting the secretion of ECM components, generating a tumour-supporting tumour microenvironment $(183,184)$. BMPs also play an important part in the vicious cycle of forming metastatic bone lesions $(59,218,223,228)$. Emerging evidence shows that the BMP signalling is also involved in the regulation of immunity. For example, BMP signalling can regulate the activation and differentiation of T cells $(229,230)$. BMP-2 could robustly activate macrophages through Smad 1/5/8 signalling pathway. However, potential roles of BMPs in immunotherapies targeted against malignancies remain to be fully investigated.

Collectively, BMP, tumour cells and the tumour microenvironment constitute a large, intricate network that regulates tumour proliferation, EMT, invasion, angiogenesis, development of metastasis and immune regulation (Fig. 6).

\section{Acknowledgements}

Not applicable.

\section{Funding}

This work was supported by a Chinese Scholarship from Cardiff University, and sponsorship by Peking University Cancer Hospital and Institute.

\section{Availability of data and materials}

Not applicable.

\section{Authors' contributions}

ZS, SC, CZ, CL and LY prepared the figures and drafted the manuscript. ZS, CZ and LY revised the manuscript. All authors read and approved the final manuscript.

\section{Ethics approval and consent to participate}

Not applicable.

\section{Patient consent for publication}

Not applicable.

\section{Competing interests}

The authors declare that they have no competing interests. 


\section{References}

1. Urist MR: Bone: Formation by autoinduction. Science 150: 893-899, 1965.

2. Ye L, Bokobza SM and Jiang WG: Bone morphogenetic proteins in development and progression of breast cancer and therapeutic potential (review). Int J Mol Med 24: 591-597, 2009.

3. Yang L, Meng F, Ma D, Xie W and Fang M: Bridging Decapentaplegic and Wingless signaling in Drosophila wings through repression of naked cuticle by Brinker. Development 140: 413-422, 2013.

4. Wu M, Chen G and Li YP: TGF- $\beta$ and BMP signaling in osteoblast, skeletal development, and bone formation, homeostasis and disease. Bone Res 4: 16009, 2016.

5. Willet SG and Mills JC: Stomach organ and cell lineage differentiation: From embryogenesis to adult homeostasis. Cell Mol Gastroenterol Hepatol 2: 546-559, 2016.

6. Todisco A: Regulation of gastric metaplasia, dysplasia, and neoplasia by bone morphogenetic protein signaling. Cell Mol Gastroenterol Hepatol 3: 339-347, 2017.

7. Tamada H, Kitazawa R, Gohji K and Kitazawa S: Epigenetic regulation of human bone morphogenetic protein 6 gene expression in prostate cancer. J Bone Miner Res 16: 487-496, 2001.

8. Guo D, Huang J and Gong J: Bone morphogenetic protein 4 (BMP4) is required for migration and invasion of breast cancer. Mol Cell Biochem 363: 179-190, 2012.

9. Ye L, Kynaston H and Jiang WG: Bone morphogenetic protein-10 suppresses the growth and aggressiveness of prostate cancer cells through a Smad independent pathway. J Urol 181: 2749-2759, 2009.

10. Cao Y, Slaney CY, Bidwell BN, Parker BS, Johnstone CN, Rautela J, Eckhardt BL and Anderson RL: BMP4 inhibits breast cancer metastasis by blocking myeloid-derived suppressor cell activity. Cancer Res 74: 5091-5102, 2014.

11. Raval P, Hsu HH, Schneider DJ, Sarras MP Jr, Masuhara K, Bonewald LF and Anderson HC: Expression of bone morphogenetic proteins by osteoinductive and non-osteoinductive human osteosarcoma cells. J Dent Res 75: 1518-1523, 1996.

12. Guo W, Gorlick R, Ladanyi M, Meyers PA, Huvos AG, Bertino JR and Healey JH: Expression of bone morphogenetic proteins and receptors in sarcomas. Clin Orthop Relat Res 175-183, 1999.

13. Gao YH and Yang LY: In situ hybridization and immunohistochemical detection of bone morphogenetic protein genes in ameloblastomas. Zhonghua Yi Xue Za Zhi 74: 621-623, 647, 1994 (In Chinese)

14. Kusafuka K, Luyten FP, De Bondt R, Hiraki Y, Shukunami C, Kayano $\mathrm{T}$ and Takemura $\mathrm{T}$ : Immunohistochemical evaluation of cartilage-derived morphogenic protein-1 and -2 in normal human salivary glands and pleomorphic adenomas. Virchows Arch 442: 482-490, 2003.

15. Hardwick JC, Kodach LL, Offerhaus GJ and van den Brink GR: Bone morphogenetic protein signalling in colorectal cancer. Nat Rev Cancer 8: 806-812, 2008.

16. Clement JH, Sanger J and Hoffken K: Expression of bone morphogenetic protein 6 in normal mammary tissue and breast cancer cell lines and its regulation by epidermal growth factor. Int J Cancer 80: 250-256, 1999.

17. Lehmann K, Janda E, Pierreux CE, Rytömaa M, Schulze A, McMahon M, Hill CS, Beug H and Downward J: Raf induces TGFbeta production while blocking its apoptotic but not invasive responses: A mechanism leading to increased malignancy in epithelial cells. Genes Dev 14: 2610-2622, 2000.

18. Oft M, Peli J, Rudaz C, Schwarz H, Beug H and Reichmann E: TGF-beta1 and Ha-Ras collaborate in modulating the phenotypic plasticity and invasiveness of epithelial tumor cells. Genes Dev 10: 2462-2477, 1996.

19. Yue J and Mulder KM: Requirement of Ras/MAPK pathway activation by transforming growth factor beta for transforming growth factor beta 1 production in a Smad-dependent pathway. J Biol Chem 275: 30765-30773, 2000

20. Wilkes MC, Mitchell H, Penheiter SG, Doré JJ, Suzuki K, Edens M, Sharma DK, Pagano RE and Leof EB: Transforming growth factor-beta activation of phosphatidylinositol 3-kinase is independent of $\mathrm{Smad} 2$ and $\mathrm{Smad} 3$ and regulates fibroblast responses via p21-activated kinase-2. Cancer Res 65: 10431-10440, 2005.

21. Chen X, Liao J, Lu Y, Duan X and Sun W: Activation of the PI3K/Akt pathway mediates bone morphogenetic protein 2 -induced invasion of pancreatic cancer cells Panc-1. Pathol Oncol Res 17: 257-261, 2011.
22. Wang SE, Shin I, Wu FY, Friedman DB and Arteaga CL: HER2/Neu (ErbB2) signaling to Rac1-Pak1 is temporally and spatially modulated by transforming growth factor beta. Cancer Res 66: 9591-9600, 2006

23. Kang MH, Oh SC, Lee HJ, Kang HN, Kim JL, Kim JS and Yoo YA: Metastatic function of BMP-2 in gastric cancer cells: The role of PI3K/AKT, MAPK, the NF-кB pathway, and MMP-9 expression. Exp Cell Res 317: 1746-1762, 2011.

24. Zhang L, Ye Y, Long X, Xiao P, Ren X and Yu J: BMP signaling and its paradoxical effects in tumorigenesis and dissemination. Oncotarget 7: 78206-78218, 2016.

25. Ye L, Mason MD and Jiang WG: Bone morphogenetic protein and bone metastasis, implication and therapeutic potential. Front Biosci (Landmark Ed) 16: 865-897, 2011.

26. Nohe A, Hassel S, Ehrlich M, Neubauer F, Sebald W, Henis YI and Knaus P: The mode of bone morphogenetic protein (BMP) receptor oligomerization determines different BMP-2 signaling pathways. J Biol Chem 277: 5330-5338, 2002.

27. Nohe A, Keating E, Knaus P and Petersen NO: Signal transduction of bone morphogenetic protein receptors. Cellular Signal 16: 291-299, 2004.

28. Shi Y and Massague J: Mechanisms of TGF-beta signaling from cell membrane to the nucleus. Cell 113: 685-700, 2003.

29. Ye L, Lewis-Russell JM, Davies G, Sanders AJ, Kynaston H and Jiang WG: Hepatocyte growth factor up-regulates the expression of the bone morphogenetic protein (BMP) receptors, BMPR-IB and BMPR-II, in human prostate cancer cells. Int J Oncol 30: 521-529, 2007.

30. Shibuya H, Yamaguchi K, Shirakabe K, Tonegawa A, Gotoh Y, Ueno N, Irie K, Nishida E and Matsumoto K: TAB1: An activator of the TAK1 MAPKKK in TGF-beta signal transduction. Science 272: 1179-1182, 1996.

31. Yamaguchi K, Nagai S, Ninomiya-Tsuji J, Nishita M, Tamai K Irie K, Ueno N, Nishida E, Shibuya $\mathrm{H}$ and Matsumoto K: XIAP, a cellular member of the inhibitor of apoptosis protein family, links the receptors to TAB1-TAK1 in the BMP signaling pathway. EMBO J 18: 179-187, 1999.

32. Yamaguchi K, Shirakabe K, Shibuya H, Irie K, Oishi I, Ueno N, Taniguchi T, Nishida E and Matsumoto K: Identification of a member of the MAPKKK family as a potential mediator of TGF-beta signal transduction. Science 270: 2008-2011, 1995.

33. Kimura N, Matsuo R, Shibuya H, Nakashima K and Taga T: BMP2-induced apoptosis is mediated by activation of the TAK1-p38 kinase pathway that is negatively regulated by Smad6. J Biol Chem 275: 17647-17652, 2000.

34. Moriguchi T, Kuroyanagi N, Yamaguchi K, Gotoh Y, Irie K, Kano T, Shirakabe K, Muro Y, Shibuya H, Matsumoto K, et al: A novel kinase cascade mediated by mitogen-activated protein kinase kinase 6 and MKK3. J Biol Chem 271: 13675-13679, 1996.

35. Ishitani T, Ninomiya-Tsuji J, Nagai S, Nishita M, Meneghini M, Barker N, Waterman M, Bowerman B, Clevers H, Shibuya H and Matsumoto K: The TAK1-NLK-MAPK-related pathway antagonizes signalling between beta-catenin and transcription factor TCF. Nature 399: 798-802, 1999.

36. Lee SW, Han SI, Kim HH and Lee ZH: TAK1-dependent activation of AP-1 and c-Jun N-terminal kinase by receptor activator of NF-kappaB. J Biochem Mol Biol 35: 371-376, 2002.

37. Shirakabe K, Yamaguchi K, Shibuya H, Irie K, Matsuda S, Moriguchi T, Gotoh Y, Matsumoto K and Nishida E: TAK1 mediates the ceramide signaling to stress-activated protein kinase/c-Jun N-terminal kinase. J Biol Chem 272: 8141-8144, 1997.

38. Alarmo EL and Kallioniemi A: Bone morphogenetic proteins in breast cancer: Dual role in tumourigenesis? Endocr Relat Cancer 17: R123-R139, 2010.

39. Gazzerro E, Gangji V and Canalis E: Bone morphogenetic proteins induce the expression of noggin, which limits their activity in cultured rat osteoblasts. J Clin Invest 102: 2106-2114, 1998.

40. Onichtchouk D, Chen YG, Dosch R, Gawantka V, Delius H, Massagué J and Niehrs C: Silencing of TGF-beta signalling by the pseudoreceptor BAMBI. Nature 401: 480-485, 1999.

41. Grotewold L, Plum M, Dildrop R, Peters T and Ruther U: Bambi is coexpressed with Bmp-4 during mouse embryogenesis. Mech Dev 100: 327-330, 2001

42. Samad TA, Rebbapragada A, Bell E, Zhang Y, Sidis Y, Jeong SJ, Campagna JA, Perusini S, Fabrizio DA, Schneyer AL, et al: DRAGON, a bone morphogenetic protein co-receptor. J Biol Chem 280: 14122-14129, 2005. 
43. Babitt JL, Zhang Y, Samad TA, Xia Y, Tang J, Campagna JA Schneyer AL, Woolf CJ and Lin HY: Repulsive guidance molecule (RGMa), a DRAGON homologue, is a bone morphogenetic protein co-receptor. J Biol Chem 280: 29820-29827, 2005.

44. Babitt JL, Huang FW, Wrighting DM, Xia Y, Sidis Y, Samad TA, Campagna JA, Chung RT, Schneyer AL, Woolf CJ, et al: Bone morphogenetic protein signaling by hemojuvelin regulates hepcidin expression. Nat Genet 38: 531-539, 2006.

45. Hayashi H, Abdollah S, Qiu Y, Cai J, Xu YY, Grinnell BW, Richardson MA, Topper JN, Gimbrone MA Jr, Wrana JL and Falb D: The MAD-related protein Smad7 associates with the TGFbeta receptor and functions as an antagonist of TGFbeta signaling. Cell 89: 1165-1173, 1997.

46. Takase M, Imamura T, Sampath TK, Takeda K, Ichijo H, Miyazono K and Kawabata M: Induction of Smad6 mRNA by bone morphogenetic proteins. Biochem Biophys Res Commun 244: 26-29, 1998.

47. Ishisaki A, Yamato K, Hashimoto S, Nakao A, Tamaki K, Nonaka K, ten Dijke P, Sugino H and Nishihara T: Differentia inhibition of Smad6 and Smad7 on bone morphogenetic proteinand activin-mediated growth arrest and apoptosis in B cells. J Biol Chem 274: 13637-13642, 1999.

48. Feng XH, Lin X and Derynck R: Smad2, Smad3 and Smad4 cooperate with $\mathrm{Sp} 1$ to induce $\mathrm{p} 15$ (Ink4B) transcription in response to TGF-beta. EMBO J 19: 5178-5193, 2000.

49. Sano Y, Harada J, Tashiro S, Gotoh-Mandeville R, Maekawa T and Ishii S: ATF-2 is a common nuclear target of Smad and TAK1 pathways in transforming growth factor-beta signaling. J Biol Chem 274: 8949-8957, 1999.

50. Cordenonsi M, Montagner M, Adorno M, Zacchigna L, Martello G, Mamidi A, Soligo S, Dupont S and Piccolo S: Integration of TGF-beta and Ras/MAPK signaling through p53 phosphorylation. Science 315: 840-843, 2007.

51. Miyazono K, Maeda S and Imamura T: Coordinate regulation of cell growth and differentiation by TGF-beta superfamily and Runx proteins. Oncogene 23: 4232-4237, 2004.

52. Germain S, Howell M, Esslemont GM and Hill CS: Homeodomain and winged-helix transcription factors recruit activated Smads to distinct promoter elements via a common Smad interaction motif. Genes Dev 14: 435-451, 2000.

53. Miyazono K, ten Dijke P and Heldin CH: TGF-beta signaling by Smad proteins. Adv Immunol 75: 115-157, 2000

54. Durand SH, Romeas A, Couble ML, Langlois D, Li JY, Magloire H, Bleicher F, Staquet MJ and Farges JC: Expression of the TGF-beta/BMP inhibitor EVI1 in human dental pulp cells. Arch Oral Biol 52: 712-719, 2007.

55. Luo K, Stroschein SL, Wang W, Chen D, Martens E, Zhou S and Zhou Q: The Ski oncoprotein interacts with the Smad proteins to repress TGFbeta signaling. Genes Dev 13: 2196-2206, 1999.

56. Spagnoli FM and Brivanlou AH: The Gata5 target, TGIF2, defines the pancreatic region by modulating BMP signals within the endoderm. Development 135: 451-461, 2008.

57. Wotton D and Massague J: Smad transcriptional corepressors in TGF beta family signaling. Curr Top Microbiol Immunol 254 145-164, 2001.

58. Zhu H, Kavsak P, Abdollah S, Wrana JL and Thomsen GH: A SMAD ubiquitin ligase targets the BMP pathway and affects embryonic pattern formation. Nature 400: 687-693, 1999.

59. Ye L, Lewis-Russell JM, Kyanaston HG and Jiang WG: Bone morphogenetic proteins and their receptor signaling in prostate cancer. Histol Histopathol 22: 1129-1147, 2007.

60. Beck SE and Carethers JM: BMP suppresses PTEN expression via RAS/ERK signaling. Cancer Biol Ther 6: 1313-1317, 2007.

61. Duchartre Y, Kim YM and Kahn M: The Wnt signaling pathway in cancer. Crit Rev Oncol Hematol 99: 141-149, 2016.

62. Veeman MT, Axelrod JD and Moon RT: A second canon. Functions and mechanisms of beta-catenin-independent Wnt signaling. Dev Cell 5: 367-377, 2003.

63. Mosimann C, Hausmann G and Basler K: Beta-catenin hits chromatin: Regulation of Wnt target gene activation. Nat Rev Mol Cell Biol 10: 276-286, 2009.

64. Moon RT: Wnt/beta-catenin pathway. Sci STKE 2005: $\mathrm{cm} 1$, 2005.

65. Teo JL and Kahn M: The Wnt signaling pathway in cellular proliferation and differentiation: A tale of two coactivators. Adv Drug Deliv Rev 62: 1149-1155, 2010.

66. Imai Y, Terai H, Nomura-Furuwatari C, Mizuno S, Matsumoto K, Nakamura T and Takaoka K: Hepatocyte growth factor contributes to fracture repair by upregulating the expression of BMP receptors. J Bone Miner Res 20: 1723-1730, 2005.
67. Zhen R, Yang J, Wang Y, Li Y, Chen B, Song Y, Ma G and Yang B: Hepatocyte growth factor improves bone regeneration via the bone morphogenetic protein 2 mediated $\mathrm{NF \kappa B}$ signaling pathway. Mol Med Rep 17: 6045-6053, 2018.

68. Luo K: Signaling cross talk between TGF- $\beta / \mathrm{smad}$ and other signaling pathways. Cold Spring Harb Perspect Biol 9: pii: a022137, 2017.

69. Labbe E, Letamendia A and Attisano L: Association of Smads with lymphoid enhancer binding factor $1 / \mathrm{T}$ cell-specific factor mediates cooperative signaling by the transforming growth factor-beta and wnt pathways. Proc Natl Acad Sci USA 97: 8358-8363, 2000.

70. Nishita M, Hashimoto MK, Ogata S, Laurent MN, Ueno N, Shibuya $\mathrm{H}$ and Cho KW: Interaction between Wnt and TGF-beta signalling pathways during formation of Spemann's organizer. Nature 403: 781-785, 2000.

71. Hussein SM, Duff EK and Sirard C: Smad4 and beta-catenin co-activators functionally interact with lymphoid-enhancing factor to regulate graded expression of Msx2. J Biol Chem 278: 48805-48814, 2003 .

72. Weng X, Zhang H, Ye J, Kan M, Liu F, Wang T, Deng J, Tan Y, He L and Liu Y: Hypermethylated Epidermal growth factor receptor (EGFR) promoter is associated with gastric cancer. Sci Rep 5: 10154, 2015.

73. Lemmon MA and Schlessinger J: Cell signaling by receptor tyrosine kinases. Cell 141: 1117-1134, 2010.

74. Sigismund S, Avanzato D and Lanzetti L: Emerging functions of the EGFR in cancer. Mol Oncol 12: 3-20, 2018.

75. de Caestecker MP, Parks WT, Frank CJ, Castagnino P, Bottaro DP, Roberts AB and Lechleider RJ: Smad2 transduces common signals from receptor serine-threonine and tyrosine kinases. Genes Dev 12: 1587-1592, 1998.

76. Brown JD, DiChiara MR, Anderson KR and Gimbrone MA Jr. and Topper JN: MEKK-1, a component of the stress (stress-activated protein kinase/c-Jun $\mathrm{N}$-terminal kinase) pathway, can selectively activate Smad2-mediated transcriptional activation in endothelial cells. J Biol Chem 274: 8797-8805, 1999.

77. Ross KR, Corey DA, Dunn JM and Kelley TJ: SMAD3 expression is regulated by mitogen-activated protein kinase kinase- 1 in epithelial and smooth muscle cells. Cell Signal 19: 923-931,2007.

78. Kretzschmar M, Doody J, Timokhina I and Massague J: A mechanism of repression of TGFbeta/ Smad signaling by oncogenic Ras. Genes Dev 13: 804-816, 1999.

79. Matsuura I, Wang G, He D and Liu F: Identification and characterization of ERK MAP kinase phosphorylation sites in Smad3. Biochemistry 44: 12546-12553, 2005.

80. Kamaraju AK and Roberts AB: Role of Rho/ROCK and p38 MAP kinase pathways in transforming growth factor-beta-mediated Smad-dependent growth inhibition of human breast carcinoma cells in vivo. J Biol Chem 280: 1024-1036, 2005.

81. Guo $X$ and Wang XF: Signaling cross-talk between TGF-beta/BMP and other pathways. Cell Res 19: 71-88, 2009.

82. Saha D, Datta PK and Beauchamp RD: Oncogenic ras represses transforming growth factor-beta /Smad signaling by degrading tumor suppressor Smad4. J Biol Chem 276: 29531-29537, 2001.

83. Liang M, Liang YY, Wrighton K, Ungermannova D, Wang XP, Brunicardi FC, Liu X, Feng XH and Lin X: Ubiquitination and proteolysis of cancer-derived Smad4 mutants by SCFSkp2. Mol Cell Biol 24: 7524-7537, 2004.

84. Brodin G, Ahgren A, ten Dijke P, Heldin CH and Heuchel R: Efficient TGF-beta induction of the Smad7 gene requires cooperation between AP-1, Sp1, and Smad proteins on the mouse Smad7 promoter. J Biol Chem 275: 29023-29030, 2000.

85. Dowdy SC, Mariani A and Janknecht R: HER2/Neu- and TAK1-mediated up-regulation of the transforming growth factor beta inhibitor Smad7 via the ETS protein ER81. J Biol Chem 278: 44377-44384, 2003

86. Uchida K, Suzuki H, Ohashi T, Nitta K, Yumura W and Nihei H: Involvement of MAP kinase cascades in Smad7 transcriptional regulation. Biochem Biophys Res Commun 289: 376-381, 2001.

87. Shaulian E and Karin M: AP-1 as a regulator of cell life and death. Nat Cell Biol 4: E131-E136, 2002.

88. Hanafusa H, Ninomiya-Tsuji J, Masuyama N, Nishita M, Fujisawa J, Shibuya H, Matsumoto K and Nishida E: Involvement of the p38 mitogen-activated protein kinase pathway in transforming growth factor-beta-induced gene expression. J Biol Chem 274: 27161-27167, 1999.

89. Jin EJ, Lee SY, Choi YA, Jung JC, Bang OS and Kang SS BMP-2-enhanced chondrogenesis involves p38 MAPK-mediated down-regulation of Wnt-7a pathway. Mol Cells 22: 353-359, 2006. 
90. Thomas DA and Massague J: TGF-beta directly targets cytotoxic $\mathrm{T}$ cell functions during tumor evasion of immune surveillance. Cancer Cell 8: 369-380, 2005

91. Monzen K, Hiroi Y, Kudoh S, Akazawa H, Oka T, Takimoto E, Hayashi D, Hosoda T, Kawabata M, Miyazono K, et al: Smads, TAK1, and their common target ATF-2 play a critical role in cardiomyocyte differentiation. J Cell Biol 153: 687-698, 2001.

92. Bakin AV, Tomlinson AK, Bhowmick NA, Moses HL and Arteaga CL: Phosphatidylinositol 3-kinase function is required for transforming growth factor beta-mediated epithelial to mesenchymal transition and cell migration. J Biol Chem 275: 36803-36810, 2000

93. Lamouille S and Derynck R: Cell size and invasion in TGF-beta-induced epithelial to mesenchymal transition is regulated by activation of the mTOR pathway. J Cell Biol 178: 437-451, 2007.

94. Ghosh-Choudhury N, Abboud SL, Nishimura R, Celeste A, Mahimainathan L and Choudhury GG: Requirement of BMP-2-induced phosphatidylinositol 3-kinase and Akt serine/threonine kinase in osteoblast differentiation and Smad-dependent BMP-2 gene transcription. J Biol Chem 277: 33361-33368, 2002.

95. He XC, Zhang J, Tong WG, Tawfik O, Ross J, Scoville DH, Tian Q, Zeng X, He X, Wiedemann LM, et al: BMP signaling inhibits intestinal stem cell self-renewal through suppression of Wnt-beta-catenin signaling. Nat Genet 36: 1117-1121, 2004.

96. Tian Q, He XC, Hood L and Li L: Bridging the BMP and Wnt pathways by PI3 kinase/Akt and 14-3-3zeta. Cell Cycle 4: 215-216, 2005.

97. Valderrama-Carvajal H, Cocolakis E, Lacerte A, Lee EH, Krystal G, Ali S and Lebrun JJ: Activin/TGF-beta induce apoptosis through Smad-dependent expression of the lipid phosphatase SHIP. Nat Cell Biol 4: 963-969, 2002.

98. Lu Z, Ghosh S, Wang Z and Hunter T: Downregulation of caveolin-1 function by EGF leads to the loss of E-cadherin, increased transcriptional activity of beta-catenin, and enhanced tumor cell invasion. Cancer Cell 4: 499-515, 2003.

99. Ji H, Wang J, Nika H, Hawke D, Keezer S, Ge Q, Fang B, Fang X, Fang D, Litchfield DW, et al: EGF-induced ERK activation promotes CK2-mediated disassociation of alpha-Catenin from beta-Catenin and transactivation of beta-Catenin. Mol Cell 36: 547-559, 2009.

100. Ye L, Lewis-Russell JM, Sanders AJ, Kynaston H and Jiang WG: HGF/SF up-regulates the expression of bone morphogenetic protein 7 in prostate cancer cells. Urol Oncol 26: 190-197, 2008

101. Jiang WG, Martin TA, Parr C, Davies G, Matsumoto K and Nakamura T: Hepatocyte growth factor, its receptor, and their potential value in cancer therapies. Crit Rev Oncol Hematol 53 35-69, 2005.

102. Davies G, Mason MD, Martin TA, Parr C, Watkins G, Lane J, Matsumoto K, Nakamura T and Jiang WG: The HGF/SF antagonist NK4 reverses fibroblast- and HGF-induced prostate tumor growth and angiogenesis in vivo. Int J Cancer 106: 348-354, 2003.

103. Martin TA, Parr C, Davies G, Watkins G, Lane J, Matsumoto K, Nakamura T, Mansel RE and Jiang WG: Growth and angiogenesis of human breast cancer in a nude mouse tumour mode is reduced by NK4, a HGF/SF antagonist. Carcinogenesis 24 1317-1323, 2003.

104. Tomioka D, Maehara N, Kuba K, Mizumoto K, Tanaka M, Matsumoto K and Nakamura T: Inhibition of growth, invasion, and metastasis of human pancreatic carcinoma cells by NK4 in an orthotopic mouse model. Cancer Res 61: 7518-7524, 2001

105. Abounader R, Ranganathan S, Lal B, Fielding K, Book A, Dietz H, Burger P and Laterra J: Reversion of human glioblastoma malignancy by U1 small nuclear RNA/ribozyme targeting of scatter factor/hepatocyte growth factor and c-met expression. J Natl Cancer Inst 91: 1548-1556, 1999.

106. Jiang WG, Grimshaw D, Martin TA, Davies G, Parr C, Watkins G, Lane J, Abounader R, Laterra J and Mansel RE: Reduction of stromal fibroblast-induced mammary tumor growth, by retroviral ribozyme transgenes to hepatocyte growth factor/scatter factor and its receptor, c-MET. Clin Cancer Res 9 4274-4281, 2003

107. Grenier A, Chollet-Martin S, Crestani B, Delarche C, El Benna J, Boutten A, Andrieu V, Durand G, Gougerot-Pocidalo MA, Aubier M and Dehoux M: Presence of a mobilizable intracellular pool of hepatocyte growth factor in human polymorphonuclear neutrophils. Blood 99: 2997-3004, 2002.
108. Taieb J, Delarche C, Paradis V, Mathurin P, Grenier A, Crestani B, Dehoux M, Thabut D, Gougerot-Pocidalo MA, Poynard T and Chollet-Martin S: Polymorphonuclear neutrophils are a source of hepatocyte growth factor in patients with severe alcoholic hepatitis. J Hepatol 36: 342-348, 2002.

109. Jaffre S, Dehoux M, Paugam C, Grenier A, Chollet-Martin S, Stern JB, Mantz J, Aubier M and Crestani B: Hepatocyte growth factor is produced by blood and alveolar neutrophils in acute respiratory failure. Am J Physiol Lung Cell Mol Physiol 282: L310-L315, 2002.

110. Nakamura T, Nawa K and Ichihara A: Partial purification and characterization of hepatocyte growth factor from serum of hepatectomized rats. Biochem Biophys Res Commun 122: 1450-1459, 1984.

111. Nakashiro K, Hayashi Y and Oyasu R: Immunohistochemical expression of hepatocyte growth factor and c-Met/HGF receptor in benign and malignant human prostate tissue. Onco Rep 10: 1149-1153, 2003.

112. Nakashiro K, Hara S, Shinohara Y, Oyasu M, Kawamata H, Shintani S, Hamakawa $\mathrm{H}$ and Oyasu R: Phenotypic switch from paracrine to autocrine role of hepatocyte growth factor in an androgen-independent human prostatic carcinoma cell line, CWR22R. Am J Pathol 165: 533-540, 2004.

113. Janovska P and Bryja V: Wnt signalling pathways in chronic lymphocytic leukaemia and B-cell lymphomas. Br J Pharmacol 174: 4701-4715, 2017.

114. Hoppler S and Moon RT: BMP-2/-4 and Wnt- 8 cooperatively pattern the Xenopus mesoderm. Mech Dev 71: 119-129, 1998.

115. Fuentealba LC, Eivers E, Ikeda A, Hurtado C, Kuroda H, Pera EM and De Robertis EM: Integrating patterning signals: Wnt/GSK3 regulates the duration of the BMP/Smad1 signal. Cell 131: 980-993, 2007.

116. Millet C, Yamashita M, Heller M, Yu LR, Veenstra TD and Zhang YE: A negative feedback control of transforming growth factor-beta signaling by glycogen synthase kinase 3-mediated Smad3 linker phosphorylation at Ser-204. J Biol Chem 284: 19808-19816, 2009.

117. Aragon E, Goerner N, Zaromytidou AI, Xi Q, Escobedo A Massagué J and Macias MJ: A Smad action turnover switch operated by WW domain readers of a phosphoserine code. Genes Dev 25: 1275-1288, 2011.

118. Fei C, Li Z, Li C, Chen Y, Chen Z, He X, Mao L, Wang X, Zeng R and Li L: Smurf1-mediated Lys29-linked nonproteolytic polyubiquitination of axin negatively regulates $\mathrm{Wnt} / \beta$-catenin signaling. Mol Cell Biol 33: 4095-4105, 2013.

119. Kim S and Jho EH: The protein stability of Axin, a negative regulator of Wnt signaling, is regulated by Smad ubiquitination regulatory factor 2 (Smurf2). J Biol Chem 285: 36420-36426, 2010.

120. Jian H, Shen X, Liu I, Semenov M, He X and Wang XF: Smad3-dependent nuclear translocation of beta-catenin is required for TGF-beta1-induced proliferation of bone marrow-derived adult human mesenchymal stem cells. Genes Dev 20: 666-674, 2006.

121. Aza-Blanc P and Kornberg TB: Ci: A complex transducer of the hedgehog signal. Trends Genet 15: 458-462, 1999.

122. Hepker J, Blackman RK and Holmgren R: Cubitus interruptus is necessary but not sufficient for direct activation of a wing-specific decapentaplegic enhancer. Development 126: 3669-3677, 1999.

123. Muller B and Basler K: The repressor and activator forms of Cubitus interruptus control Hedgehog target genes through common generic gli-binding sites. Development 127: 2999-3007, 2000 .

124. Dennler S, Andre J, Alexaki I, Li A, Magnaldo T, ten Dijke P, Wang XJ, Verrecchia F and Mauviel A: Induction of sonic hedgehog mediators by transforming growth factor-beta: Smad3-dependent activation of Gli2 and Gli1 expression in vitro and in vivo. Cancer Res 67: 6981-6986, 2007.

125. Blokzijl A, Dahlqvist C, Reissmann E, Falk A, Moliner A, Lendahl U and Ibáñez CF: Cross-talk between the Notch and TGF-beta signaling pathways mediated by interaction of the Notch intracellular domain with Smad3. J Cell Biol 163: 723-728, 2003.

126. Asano N, Watanabe T, Kitani A, Fuss IJ and Strober W: Notch1 signaling and regulatory $\mathrm{T}$ cell function. J Immunol 180 : 2796-2804, 2008.

127. Samon JB, Champhekar A, Minter LM, Telfer JC, Miele L, Fauq A, Das P, Golde TE and Osborne BA: Notch1 and TGFbeta1 cooperatively regulate Foxp3 expression and the maintenance of peripheral regulatory T cells. Blood 112: 1813-1821, 2008. 
128. Ostroukhova M, Qi Z, Oriss TB, Dixon-McCarthy B, Ray P and Ray A: Treg-mediated immunosuppression involves activation of the Notch-HES1 axis by membrane-bound TGF-beta. J Clin Invest 116: 996-1004, 2006.

129. U1loa L, Doody J and Massague J: Inhibition of transforming growth factor-beta/SMAD signalling by the interferon-gamma/STAT pathway. Nature 397: 710-713, 1999.

130. Ishida Y, Kondo T, Takayasu T, Iwakura Y and Mukaida N: The essential involvement of cross-talk between IFN-gamma and TGF-beta in the skin wound-healing process. J Immunol 172 1848-1855, 2004.

131. Jenkins BJ, Grail D, Nheu T, Najdovska M, Wang B, Waring P, Inglese M, McLoughlin RM, Jones SA, Topley $\mathrm{N}$, et al: Hyperactivation of Stat3 in gp130 mutant mice promotes gastric hyperproliferation and desensitizes TGF-beta signaling. Nat Med 11: 845-852, 2005.

132. Huang M, Sharma S, Zhu LX, Keane MP, Luo J, Zhang L, Burdick MD, Lin YQ, Dohadwala M, Gardner B, et al: IL-7 inhibits fibroblast TGF-beta production and signaling in pulmonary fibrosis. J Clin Invest 109: 931-937, 2002.

133. Letterio JJ and Roberts AB: Regulation of immune responses by TGF-beta. Annu Rev Immunol 16: 137-161, 1998.

134. Kang Y, Siegel PM, Shu W, Drobnjak M, Kakonen SM, Cordón-Cardo C, Guise TA and Massagué J: A multigenic program mediating breast cancer metastasis to bone. Cancer Cell 3: 537-549, 2003.

135. Kang Y, He W, Tulley S, Gupta GP, Serganova I, Chen CR, Manova-Todorova K, Blasberg R, Gerald WL and Massagué J: Breast cancer bone metastasis mediated by the Smad tumor suppressor pathway. Proc Natl Acad Sci USA 102: 13909-13914, 2005.

136. Fong YC, Maa MC, Tsai FJ, Chen WC, Lin JG, Jeng LB, Yang RS, Fu WM and Tang CH: Osteoblast-derived TGF-beta1 stimulates IL-8 release through AP-1 and NF-kappaB in human cancer cells. J Bone Miner Res 23: 961-970, 2008.

137. Tseng JC, Chen HF and Wu KJ: A twist tale of cancer metastasis and tumor angiogenesis. Histol Histopathol 30: 1283-1294, 2015.

138. Ye L and Jiang WG: Bone morphogenetic proteins in tumour associated angiogenesis and implication in cancer therapies. Cancer Lett 380: 586-597, 2016.

139. Goumans MJ, Valdimarsdottir G, Itoh S, Rosendahl A, Sideras P and ten Dijke P: Balancing the activation state of the endothelium via two distinct TGF-beta type I receptors. EMBO J 21 1743-1753, 2002.

140. Yamashita H, Shimizu A, Kato M, Nishitoh H, Ichijo H, Hanyu A, Morita I, Kimura M, Makishima F and Miyazono K: Growth/differentiation factor-5 induces angiogenesis in vivo Exp Cell Res 235: 218-226, 1997.

141. Mori S, Yoshikawa H, Hashimoto J, Ueda T, Funai H, Kato M and Takaoka K: Antiangiogenic agent (TNP-470) inhibition of ectopic bone formation induced by bone morphogenetic protein-2. Bone 22: 99-105, 1998

142. Yeh LC and Lee JC: Osteogenic protein-1 increases gene expression of vascular endothelial growth factor in primary cultures of fetal rat calvaria cells. Mol Cell Endocrinol 153: 113-124, 1999.

143. Glienke J, Schmitt AO, Pilarsky C, Hinzmann B, Weiss B, Rosenthal A and Thierauch KH: Differential gene expression by endothelial cells in distinct angiogenic states. Eur J Biochem 267: 2820-2830, 2000.

144. Langenfeld EM and Langenfeld J: Bone morphogenetic protein-2 stimulates angiogenesis in developing tumors. Molc Cancer Res 2: 141-149, 2004.

145. Finkenzeller G, Hager S and Stark GB: Effects of bone morphogenetic protein 2 on human umbilical vein endothelial cells Microvasc Res 84: 81-85, 2012.

146. Willette RN, Gu JL, Lysko PG, Anderson KM, Minehart H and Yue T: BMP-2 gene expression and effects on human vascular smooth muscle cells. J Vasc Re 36: 120-125, 1999.

147. Dorai H, Vukicevic S and Sampath TK: Bone morphogenetic protein-7 (osteogenic protein-1) inhibits smooth muscle cell proliferation and stimulates the expression of markers that are characteristic of SMC phenotype in vitro. J Cell Physiol 184 $37-45,2000$

148. Morrell NW, Yang X, Upton PD, Jourdan KB, Morgan N, Sheares KK and Trembath RC: Altered growth responses of pulmonary artery smooth muscle cells from patients with primary pulmonary hypertension to transforming growth factor-beta(1) and bone morphogenetic proteins. Circulation 104: 790-795, 2001.
149. David L, Mallet C, Mazerbourg S, Feige JJ and Bailly S: Identification of BMP9 and BMP10 as functional activators of the orphan activin receptor-like kinase 1 (ALK1) in endothelial cells. Blood 109: 1953-1961, 2007.

150. Regazzoni C, Winterhalter KH and Rohrer L: Type I collagen induces expression of bone morphogenetic protein receptor type II. Biochem Biophys Res Commun 283: 316-322, 2001.

151. Nakagawa T, Li JH, Garcia G, Mu W, Piek E, Böttinger EP, Chen Y, Zhu HJ, Kang DH, Schreiner GF, et al: TGF-beta induces proangiogenic and antiangiogenic factors via parallel but distinct Smad pathways. Kidney Int 66: 605-613, 2004.

152. Han SU, Kim HT, Seong DH, Kim YS, Park YS, Bang YJ, Yang HK and Kim SJ: Loss of the Smad3 expression increases susceptibility to tumorigenicity in human gastric cancer. Oncogene 23: 1333-1341, 2004.

153. Dai J, Kitagawa Y, Zhang J, Yao Z, Mizokami A, Cheng S, Nör J, McCauley LK, Taichman RS and Keller ET: Vascular endothelial growth factor contributes to the prostate cancer-induced osteoblast differentiation mediated by bone morphogenetic protein. Cancer Res 64: 994-999, 2004

154. Stabile H, Mitola S, Moroni E, Belleri M, Nicoli S, Coltrini D, Peri F, Pessi A, Orsatti L, Talamo F, et al: Bone morphogenic protein antagonist Drm/gremlin is a novel proangiogenic factor. Blood 109: 1834-1840, 2007

155. Akiyama I, Yoshino O, Osuga Y, Shi J, Harada M, Koga K, Hirota Y, Hirata T, Fujii T, Saito S and Kozuma S: Bone morphogenetic protein 7 increased vascular endothelial growth factor (VEGF)-a expression in human granulosa cells and VEGF receptor expression in endothelial cells. Reprod Sci 21: 477-482, 2014.

156. Raida M, Clement JH, Leek RD, Ameri K, Bicknell R, Niederwieser D and Harris AL: Bone morphogenetic protein 2 (BMP-2) and induction of tumor angiogenesis. J Cancer Res Clin Oncol 131: 741-750, 2005

157. Scharpfenecker M, van Dinther M, Liu Z, van Bezooijen RL, Zhao Q, Pukac L, Löwik CW and ten Dijke P: BMP-9 signals via ALK1 and inhibits bFGF-induced endothelial cell proliferation and VEGF-stimulated angiogenesis. J Cell Sci 120: 964-972, 2007.

158. Zabkiewicz C, Resaul J, Hargest R, Jiang WG and Ye L: Bone morphogenetic proteins, breast cancer, and bone metastases: Striking the right balance. Endocr Relat Cancer 24: R349-R366, 2017.

159. Ramoshebi LN and Ripamonti U: Osteogenic protein-1, a bone morphogenetic protein, induces angiogenesis in the chick chorioallantoic membrane and synergizes with basic fibroblast growth factor and transforming growth factor-beta1. Anat Rec 259: 97-107, 2000.

160. Larue L and Bellacosa A: Epithelial-mesenchymal transition in development and cancer: Role of phosphatidylinositol 3 kinase/AKT pathways. Oncogene 24: 7443-7454, 2005.

161. Lamouille S, Xu J and Derynck R: Molecular mechanisms of epithelial-mesenchymal transition. Nat Rev Mol Cell Biol 15: 178-196, 2014

162. Nakajima Y, Yamagishi T, Hokari S and Nakamura $\mathrm{H}$ : Mechanisms involved in valvuloseptal endocardial cushion formation in early cardiogenesis: Roles of transforming growth factor (TGF)-beta and bone morphogenetic protein (BMP). Anat Rec 258: 119-127, 2000.

163. Romano LA and Runyan RB: Slug is an essential target of TGFbeta2 signaling in the developing chicken heart. Dev Biol 223: 91-102, 2000.

164. Yang S, Zhong C, Frenkel B, Reddi AH and Roy-Burman P: Diverse biological effect and Smad signaling of bone morphogenetic protein 7 in prostate tumor cells. Cancer Res 65: 5769-5777, 2005.

165. Montesano R: Bone morphogenetic protein-4 abrogates lumen formation by mammary epithelial cells and promotes invasive growth. Biochem Biophys Res Commun 353: 817-822, 2007.

166. Piek E, Moustakas A, Kurisaki A, Heldin CH and ten Dijke P: TGF-(beta) type I receptor/ALK-5 and Smad proteins mediate epithelial to mesenchymal transdifferentiation in NMuMG breast epithelial cells. J Cell Sci 112: 4557-4568, 1999.

167. Yang S, Du J, Wang Z, Yuan W, Qiao Y, Zhang M, Zhang J, Gao S, Yin J, Sun B and Zhu T: BMP-6 promotes E-cadherin expression through repressing deltaEF1 in breast cancer cells. BMC Cancer 7: 211, 2007

168. Clement JH, Raida M, Sanger J, Bicknell R, Liu J, Naumann A, Geyer A, Waldau A, Hortschansky P, Schmidt A, et al: Bone morphogenetic protein 2 (BMP-2) induces in vitro invasion and in vivo hormone independent growth of breast carcinoma cells. Int J Oncol 27: 401-407, 2005. 
169. Katsuno Y, Hanyu A, Kanda H, Ishikawa Y, Akiyama F, Iwase T, Ogata E, Ehata S, Miyazono K and Imamura T: Bone morphogenetic protein signaling enhances invasion and bone metastasis of breast cancer cells through Smad pathway. Oncogene 27: 6322-6333, 2008

170. Gautschi O, Tepper CG, Purnell PR, Izumiya Y, Evans CP, Green TP, Desprez PY, Lara PN, Gandara DR, Mack PC and Kung HJ: Regulation of Id1 expression by SRC: Implications for targeting of the bone morphogenetic protein pathway in cancer. Cancer Res 68: 2250-2258, 2008.

171. Buijs JT, Henriquez NV, van Overveld PG, van der Horst G, Que I, Schwaninger R, Rentsch C, Ten Dijke P, Cleton-Jansen AM, Driouch K, et al: Bone morphogenetic protein 7 in the development and treatment of bone metastases from breast cancer. Cancer Res 67: 8742-8751, 2007.

172. Du J, Yang S, An D, Hu F, Yuan W, Zhai C and Zhu T: BMP-6 inhibits microRNA-21 expression in breast cancer through repressing deltaEF1 and AP-1. Cell Res 19: 487-496, 2009.

173. de Boeck M, Cui C, Mulder AA, Jost CR, Ikeno S and Ten Dijke P: Smad6 determines BMP-regulated invasive behaviour of breast cancer cells in a zebrafish xenograft model. Sci Rep 6: 24968, 2016.

174. Luna-Zurita L, Prados B, Grego-Bessa J, Luxán G, del Monte G, Benguría A, Adams RH, Pérez-Pomares JM and de la Pompa JL: Integration of a Notch-dependent mesenchymal gene program and Bmp2-driven cell invasiveness regulates murine cardiac valve formation. J Clin Invest 120: 3493-3507, 2010.

175. Ma L, Lu MF, Schwartz RJ and Martin JF: Bmp2 is essential for cardiac cushion epithelial-mesenchymal transition and myocardial patterning. Development 132: 5601-5611, 2005.

176. Dyer L, Lockyer P, Wu Y, Saha A, Cyr C, Moser M, Pi X and Patterson C: BMPER promotes epithelial-mesenchymal transition in the developing cardiac cushions. PLoS One 10: e0139209, 2015.

177. Kang MH, Kang HN, Kim JL, Kim JS, Oh SC and Yoo YA: Inhibition of PI3 kinase/Akt pathway is required for BMP2-induced EMT and invasion. Oncol Rep 22: 525-534, 2009.

178. Kang MH, Kim JS, Seo JE, Oh SC and Yoo YA: BMP2 accelerates the motility and invasiveness of gastric cancer cells via activation of the phosphatidylinositol 3-kinase (PI3K)/Akt pathway. Exp Cell Res 316: 24-37, 2010.

179. Owens P, Polikowsky H, Pickup MW, Gorska AE, Jovanovic B, Shaw AK, Novitskiy SV, Hong CC and Moses HL: Bone Morphogenetic Proteins stimulate mammary fibroblasts to promote mammary carcinoma cell invasion. PLoS One 8: e67533, 2013

180. Scherberich A, Tucker RP, Degen M, Brown-Luedi M, Andres AC and Chiquet-Ehrismann R: Tenascin-W is found in malignant mammary tumors, promotes alpha 8 integrin-dependent motility and requires p38MAPK activity for BMP-2 and TNF-alpha induced expression in vitro. Oncogene 24: 1525-1532, 2005.

181. Giussani M, Triulzi T, Sozzi G and Tagliabue E: Tumor extracellular matrix remodeling: New perspectives as a circulating tool in the diagnosis and prognosis of solid tumors. Cells 8: pii: E81, 2019.

182. Eble JA and Niland S: The extracellular matrix in tumor progression and metastasis. Clin Exp Metastasis 36: 171-198, 2019.

183. Zhong L, Wang X, Wang S, Yang L, Gao H and Yang C: The anti-fibrotic effect of bone morphogenic protein-7(BMP-7) on liver fibrosis. Int J Med Sci 10: 441-450, 2013.

184. Li H, Cui D, Zhao F, Huo L, Hu J and Zeng J: BMP-2 is involved in scleral remodeling in myopia development. PLoS One 10: e0125219, 2015.

185. Chen CC and Lau LF: Functions and mechanisms of action of CCN matricellular proteins. Int J Biochem Cell Biol 41: 771-783, 2009.

186. Leask A and Abraham DJ: All in the CCN family: Essential matricellular signaling modulators emerge from the bunker. J Cell Sci 119: 4803-4810, 2006.

187. Holbourn KP, Acharya KR and Perbal B: The CCN family of proteins: Structure-function relationships. Trends Biochem Sci 33: 461-473, 2008.

188. Kireeva ML, Mo FE, Yang GP and Lau LF: Cyr61, a product of a growth factor-inducible immediate-early gene, promotes cell proliferation, migration, and adhesion. Mol Cell Biol 16: 1326-1334, 1996.

189. Yosimichi G, Nakanishi T, Nishida T, Hattori T, Takano-Yamamoto $\mathrm{T}$ and Takigawa M: CTGF/Hcs24 induces chondrocyte differentiation through a p38 mitogen-activated protein kinase (p38MAPK), and proliferation through a p44/42 MAPK/extracellular-signal regulated kinase (ERK). Eur J Biochem 268: 6058-6065, 2001.
190. Baguma-Nibasheka M and Kablar B: Pulmonary hypoplasia in the connective tissue growth factor (Ctgf) null mouse. Dev Dyn 237: 485-493, 2008.

191. Chen CC, Chen N and Lau LF: The angiogenic factors Cyr61 and connective tissue growth factor induce adhesive signaling in primary human skin fibroblasts. J Biol Chem 276: 10443-10452, 2001.

192. Liu H, Dong W, Lin Z, Lu J, Wan H, Zhou Z and Liu Z: CCN4 regulates vascular smooth muscle cell migration and proliferation. Mol Cells 36: 112-118, 2013.

193. Schutze N, Schenk R, Fiedler J, Mattes T, Jakob F and Brenner RE: CYR61/CCN1 and WISP3/CCN6 are chemoattractive ligands for human multipotent mesenchymal stroma cells. BMC Cell Biol 8: 45, 2007.

194. Leu SJ, Lam SC and Lau LF: Pro-angiogenic activities of CYR61 (CCN1) mediated through integrins alphavbeta3 and alpha6beta1 in human umbilical vein endothelial cells. J Biol Chem 277: 46248-46255, 2002.

195. Todorovic V, Chen CC, Hay N and Lau LF: The matrix protein CCN1 (CYR61) induces apoptosis in fibroblasts. J Cell Biol 171: $559-568,2005$.

196. Kubota S and Takigawa M: CCN family proteins and angiogenesis: from embryo to adulthood. Angiogenesis 10: 1-11, 2007.

197. Kular L, Pakradouni J, Kitabgi P, Laurent M and Martinerie C: The CCN family: A new class of inflammation modulators? Biochimie 93: 377-388, 2011.

198. Bai T, Chen CC and Lau LF: Matricellular protein CCN1 activates a proinflammatory genetic program in murine macrophages. J Immunol 184: 3223-3232, 2010.

199. Abreu JG, Ketpura NI, Reversade B and De Robertis EM: Connective-tissue growth factor (CTGF) modulates cell signalling by BMP and TGF-beta. Nat Cell Biol 4: 599-604, 2002.

200. Minamizato T, Sakamoto K, Liu T, Kokubo H, Katsube K, Perbal B, Nakamura S and Yamaguchi A: CCN3/NOV inhibits BMP-2-induced osteoblast differentiation by interacting with BMP and Notch signaling pathways. Biochem Biophys Res Commun 354: 567-573, 2007.

201. Ono M, Inkson CA, Kilts TM and Young MF: WISP-1/CCN4 regulates osteogenesis by enhancing BMP-2 activity. J Bone Miner Res 26: 193-208, 2011.

202. Nakamura Y, Weidinger G,Liang JO, Aquilina-Beck A, Tamai K, Moon RT and Warman ML: The CCN family member Wisp3, mutant in progressive pseudorheumatoid dysplasia, modulates BMP and Wnt signaling. J Clin Invest 117: 3075-3086, 2007.

203. Kubota S, Kawaki H, Kondo S, Yosimichi G, Minato M, Nishida T, Hanagata H, Miyauchi A and Takigawa M: Multiple activation of mitogen-activated protein kinases by purified independent CCN2 modules in vascular endothelial cells and chondrocytes in culture. Biochimie 88: 1973-1981, 2006.

204. Maeda A, Nishida T, Aoyama E, Kubota S, Lyons KM, Kuboki T and Takigawa M: CCN family $2 /$ connective tissue growth factor modulates BMP signalling as a signal conductor, which action regulates the proliferation and differentiation of chondrocytes. J Biochem 145: 207-216, 2009.

205. Maeda S: An impact of CCN2-BMP-2 complex upon chondrocyte biology: Evoking a signalling pathway bypasses ERK and Smads? J Biochem 150: 219-221, 2011.

206. Xiao F, Qiu H, Cui H, Ni X, Li J, Liao W, Lu L and Ding K: MicroRNA-885-3p inhibits the growth of HT-29 colon cancer cell xenografts by disrupting angiogenesis via targeting BMPR1A and blocking BMP/Smad/Id1 signaling. Oncogene 34: 1968-1978, 2015.

207. Nishida N, Nagahara M, Sato T, Mimori K, Sudo T, Tanaka F, Shibata K, Ishii H, Sugihara K, Doki Y and Mori M: Microarray analysis of colorectal cancer stromal tissue reveals upregulation of two oncogenic miRNA clusters. Clin Cancer Res 18: 3054-3070, 2012.

208. Okuda S, Myoui A, Nakase T, Wada E, Yonenobu K and Yoshikawa H: Ossification of the ligamentum flavum associated with osteoblastoma: A report of three cases. Skeletal Radiol 30: 402-406, 2001.

209. Khurana JS, Ogino S, Shen T, Parekh H, Scherbel U, DeLong W, Feldman MD, Zhang PJ, Wolfe HJ and Alman BA: Bone morphogenetic proteins are expressed by both bone-forming and non-bone-forming lesions. Arch Pathol Lab Med 128: 1267-1269, 2004.

210. Kudo N, Ogose A, Ariizumi T, Kawashima H, Hotta T, Hatano H, Morita T, Nagata M, Siki Y, Kawai A, et al: Expression of bone morphogenetic proteins in giant cell tumor of bone. Anticancer Res 29: 2219-2225, 2009. 
211. Urist MR, Grant TT, Lindholm TS, Mirra JM, Hirano $H$ and Finerman GA: Induction of new-bone formation in the host bed by human bone-tumor transplants in athymic nude mice. J Bone Joint Surg Am 61: 1207-1216, 1979.

212. Anderson HC, Hsu HH, Raval P, Hunt TR, Schwappach JR, Morris DC and Schneider DJ: The mechanism of bone induction and bone healing by human osteosarcoma cell extracts. Clin Orthop Relat Res 129-134, 1995.

213. Hara A, Ikeda T, Nomura S, Yagita H, Okumura K and Yamauchi Y: In vivo implantation of human osteosarcoma cells in nude mice induces bones with human-derived osteoblasts and mouse-derived osteocytes. Lab Invest 75: 707-717, 1996.

214. Ishiyama M, Relyea-Chew A, Longstreth WT and Lewis DH: Impact of decompressive craniectomy on brain perfusion scintigraphy as an ancillary test for brain death diagnosis. Ann Nucl Med 33: 842-847, 2019.

215. Yoshikawa H, Rettig WJ, Takaoka K, Alderman E, Rup B, Rosen V, Wozney JM, Lane JM, Huvos AG and Garin-Chesa P: Expression of bone morphogenetic proteins in human osteosarcoma. Immunohistochemical detection with monoclonal antibody. Cancer 73: 85-91, 1994

216. Sulzbacher I, Birner P, Trieb K, Pichlbauer E and Lang S: The expression of bone morphogenetic proteins in osteosarcoma and its relevance as a prognostic parameter. J Clin Pathol 5: 381-385, 2002.

217. Li B, Yang Y, Jiang S, Ni B, Chen $\mathrm{K}$ and Jiang L: Adenovirus-mediated overexpression of BMP-9 inhibits human osteosarcoma cell growth and migration through downregulation of the PI3K/AKT pathway. Int J Oncol 41: 1809-1819, 2012.

218. Ye L, Kynaston HG and Jiang WG: Bone metastasis in prostate cancer: Molecular and cellular mechanisms (Review). Int J Mol Med 20: 103-111, 2007.

219. Masuda H, Fukabori Y, Nakano K, Takezawa Y, CSuzuki T and Yamanaka H: Increased expression of bone morphogenetic protein-7 in bone metastatic prostate cancer. Prostate 54: 268-274, 2003.

220. Thomas R, True LD, Lange PH and Vessella RL: Placental bone morphogenetic protein (PLAB) gene expression in normal, pre-malignant and malignant human prostate: Relation to tumor development and progression. Int J Cancer 93: 47-52, 2001.

221. Secondini C, Wetterwald A, Schwaninger R, Thalmann GN and Cecchini MG: The role of the BMP signaling antagonist noggin in the development of prostate cancer osteolytic bone metastasis. PLoS One 6: e16078, 2011.
222. Schwaninger R, Rentsch CA, Wetterwald A, van der Horst G, van Bezooijen RL, van der Pluijm G, Löwik CW, Ackermann K, Pyerin W, Hamdy FC, et al: Lack of noggin expression by cancer cells is a determinant of the osteoblast response in bone metastases. Am J Pathol 170: 160-175, 2007.

223. Brubaker KD, Corey E, Brown LG and Vessella RL: Bone morphogenetic protein signaling in prostate cancer cell lines. J Cell Biochem 91: 151-160, 2004.

224. Necchi A, Giannatempo P, Mariani L, Farè E, Raggi D, Pennati M, Zaffaroni N, Crippa F, Marchianò A, Nicolai N, et al: PF-03446962, a fully-human monoclonal antibody against transforming growth-factor $\beta$ (TGF $\beta$ ) receptor ALK1, in pre-treated patients with urothelial cancer: An open label, single-group, phase 2 trial. Invest New Drugs 32: 555-560, 2014.

225. Mitchell D, Pobre EG, Mulivor AW, Grinberg AV, Castonguay R, Monnell TE, Solban N, Ucran JA, Pearsall RS, Underwood KW, et al: ALK1-Fc inhibits multiple mediators of angiogenesis and suppresses tumor growth. Mol Cancer Ther 9: 379-388, 2010

226. Liu Y, Tian H, Blobe GC, Theuer CP, Hurwitz HI and Nixon AB: Effects of the combination of TRC105 and bevacizumab on endothelial cell biology. Invest New Drugs 32: 851-859, 2014.

227. Sun Z, Liu C, Jiang WG and Ye L: Deregulated bone morphogenetic proteins and their receptors are associated with disease progression of gastric cancer. Comput Struct Biotechnol J 18 $177-188,2020$

228. Hullinger TG, Taichman RS, Linseman DA and Somerman MJ: Secretory products from PC-3 and MCF-7 tumor cell lines upregulate osteopontin in MC3T3-E1 cells. J Cell Biochem 78: 607-616, 2000.

229. Yoshioka Y, Ono M, Osaki M, Konishi I and Sakaguchi S Differential effects of inhibition of bone morphogenic protein (BMP) signalling on T-cell activation and differentiation. Eur J Immunol 42: 749-759, 2012.

230. Martinez VG, Sacedon R, Hidalgo L, Valencia J, Fernández-Sevilla LM, Hernández-López C, Vicente A and Varas A: The BMP pathway participates in human naive CD4+ T cell activation and homeostasis. PLoS One 10: e0131453, 2015. 